\title{
NMR and EPR Study of Homolysis of Diastereomeric Alkoxyamines
}

\author{
Sergey Cherkasov ${ }^{1,2}$, Dmitriy Parkhomenko ${ }^{1}$ (), Alexander Genaev ${ }^{1}$, Georgii Salnikov ${ }^{1}$, \\ Mariya Edeleva ${ }^{1}$, Denis Morozov ${ }^{1}\left(\mathbb{D}\right.$, Tatyana Rybalova ${ }^{1}{ }^{(D)}$, Igor Kirilyuk ${ }^{1}$, \\ Sylvain R. A. Marque ${ }^{3}$ and Elena Bagryanskaya ${ }^{1, * \mathbb{D}}$ \\ 1 N. N. Vorozhtsov Novosibirsk Institute of Organic Chemistry SB RAS, Pr. Lavrentjeva 9, 630090 Novosibirsk, \\ Russia; scher@nioch.nsc.ru (S.C.); parkhomenko@nioch.nsc.ru (D.P.); genaev@nioch.nsc.ru (A.G.); \\ sge@nioch.nsc.ru (G.S.); edeleva@nioch.nsc.ru (M.E.); m_falcon@nioch.nsc.ru (D.M.); \\ rybalova@nioch.nsc.ru (T.R.); kirilyuk@nioch.nsc.ru (I.K.) \\ 2 National Research University—Novosibirsk State University, 630090 Novosibirsk, Russia \\ 3 Aix Marseille Univ, CNRS, ICR, UMR 7273, case 551, Avenue Escadrille Normandie-Niemen, \\ 13397 Marseille CEDEX 20, France; Sylvain.marque@univ-amu.fr \\ * Correspondence: egbagryanskaya@nioch.nsc.ru
}

Academic Editor: Derek J. McPhee

Received: 10 October 2020; Accepted: 30 October 2020; Published: 1 November 2020

\begin{abstract}
Three alkoxyamines based on imidazoline radicals with a pyridine functional group-potential initiators of nitroxide-mediated, controlled radical polymerization-were synthesized. Electron Paramagnetic Resonance (EPR) measurements reveal biexponential kinetics for the thermolysis for diastereomeric alkoxyamines and monoexponential kinetics for an achiral alkoxyamine. For comparison, the thermolysis of all three alkoxyamines was studied by NMR in the presence of three different scavengers, namely tetramethylpiperidine-N-oxyl (TEMPO), thiophenol $(\mathrm{PhSH})$, and $\beta$-mercaptoethanol (BME), and detailed analysis of products was performed. NMR differentiates between $N$-inversion, epimerization, and homolysis reactions. The choice of scavenger is crucial for making a reliable and accurate estimate of the true homolysis rate constant.
\end{abstract}

Keywords: nitroxide; alkoxyamine; nitroxide mediated polymerization; kinetics; scavenger; imidazoline radical; homolysis; nitrogen inversion; chirality; stereoisomerization

\section{Introduction}

Alkoxyamines have been used for three decades [1] as initiators in Nitroxide-Mediated Polymerization (NMP) [2-15]. The main parameters determining the applicability of alkoxyamines for NMP are the rate constants of their homolysis, $k_{d}$, the rate of recombination of the corresponding alkyl and nitroxide radicals, $k_{c}$ (Scheme 1), and the absence of substantial side reactions. Each of the $k_{d}$ and $k_{c}$ rate constants depend on the structure of both the nitroxide and the alkyl radicals. The equilibrium constants vary over a wide range depending on the steric and/or electronic effects of substituents in both the nitroxyl [16-19] and the alkyl parts [19-22]. In addition, the alkoxyamine homolysis parameters can be varied via the introduction of functional groups capable of reversible protonation [23-25], hydrogen bonding [26] or coordination with metals [21,27-29] (for example, pyridine or $\mathrm{OH}$ groups) in so-called "switchable" alkoxyamines [30-32]; another such factor is light in photo-cleavable alkoxyamines [33]. For example, the introduction of a pyridine group into the alkoxyamine produced up to a 30-fold increase or decrease of $k_{d}$ upon complexation [21,28-30].

In the present work, we investigate the homolysis of alkoxyamines composed of imidazoline radicals with a pyridine functional group capable of complexation with metals (Chart 1). Sterically hindered imidazoline radicals have shown their applicability to NMPs [34]. However, 
the introduction of bulky groups often leads to chiral alkoxyamines, which raises the question of whether the rate $k_{d}$ and $k_{c}$ constants can be different for different stereoisomers. In particular, Ananchenko et al. studied tetramethylpiperidine-N-oxyl (TEMPO) and N-(2-methylpropan-2-yl)$\mathrm{N}$-(1-diethylphosphono-2,2-dimethylpropyl)-aminoxyl)-based alkoxyamines by ${ }^{1} \mathrm{H}$ and ${ }^{31} \mathrm{P} \mathrm{NMR}$ spectroscopy [35-37]. They showed that the diastereomeric excess upon homolysis and reformation of the diastereomeric alkoxyamines depends strongly on the structure of both the nitroxyl and the released alkyl part.

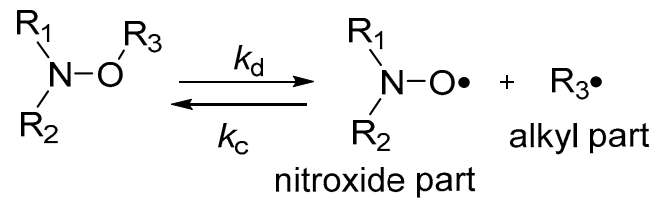

Scheme 1. C-ON bond homolysis in alkoxyamines.<smiles>CCC1(CC)C(C)=N[C@](C)(c2ccccn2)N1O</smiles>

$1^{\circ}$<smiles>CCOC(=O)[C@H](ON1C(CC)(CC)C(C)=N[C@]1(C)c1ccccn1)c1ccccc1</smiles>

$2^{\mathrm{RS} / \mathrm{SR}}$

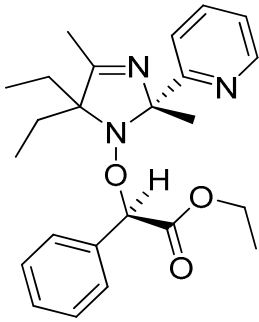

$2^{\text {RR/SS }}$<smiles>CCC1(CC)N=C(C)C(C)(c2ccccn2)N1OC(C)(C)C(=O)OC(C)(C)C</smiles>

3<smiles>CC1(C)CCCC(C)(C)N1O[O]</smiles>

TEMPO<smiles>Sc1ccccc1</smiles>

PhSH<smiles>OCCS</smiles>

BME

Chart 1. Structures of the nitroxide $\left(\mathbf{1}^{\bullet}\right)$, alkoxyamines $\left(2^{\mathrm{RR} / \mathrm{SS}}, 2^{\mathrm{RS} / \mathrm{RS}}, 3\right)$, and scavengers (TEMPO, thiophenol (PhSH), $\beta$-mercaptoethanol (BME)).

The coupling of a chiral nitroxyl radical with a prochiral alkyl radical produces an alkoxyamine exhibiting two chiral centers: one on the alkyl fragment and one on the nitroxyl fragment. In addition, the $N$-atom could be considered as a third pseudo-chiral center because of its three different substituent groups, with its electron lone pair as the fourth group. The chiral nitrogen implies the possibility of configuration inversion at the $N$-atom through a flip-flop or inversion process. These three chiral centers could undergo two independent processes: (a) nitrogen inversion and (b) stereoisomerization of the alkyl part following alkoxyamine homolysis and recombination (Scheme 2). Hereafter, we will refer to this second process as epimerization.

The homolysis of alkoxyamines commonly has a monoexponential time dependence, and consequently, EPR is often used to study the kinetics of the homolysis reaction. In such experiments, the oxygen dissolved in the sample is used as a scavenger for the alkyl radicals, so that the increasing nitroxyl radical concentration reveals the kinetics of the homolysis reaction [38]. However, this approach is not useful for the more complicated, non-monoexponential kinetics caused by side reactions. In such cases, NMR spectroscopy is used to detect and monitor the reaction intermediates and final products [39-41]. Here, we used three different scavengers, namely TEMPO, thiophenol $(\mathrm{PhSH})$, and $\beta$-mercaptoethanol (BME) (Chart 1), to show the importance of the selection of a radical trap for NMR measurements of different alkoxyamines. We examine how various processes can 
manifest themselves and show that only a careful analysis by the NMR method allows us to draw conclusions about the processes that take place.

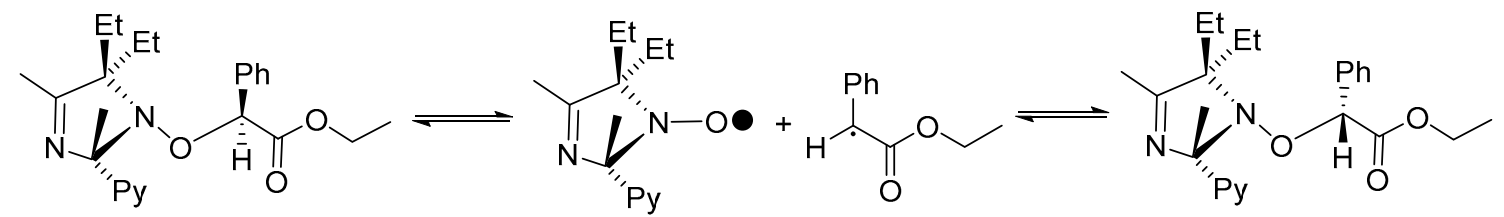<smiles></smiles>

Scheme 2. Epimerization and thermolysis in the presence of a scavenger.

\section{Results and Discussion}

\subsection{Nitrogen Inversion}

Two diastereomers $2^{\mathrm{RS} / \mathrm{SR}}$ and $\mathbf{2}^{\mathrm{RR} / \mathrm{SS}}$ were studied by NMR in the 265-331 K temperature range. Both diastereomers were found to undergo $N$-inversion: for the $2^{\mathrm{RS} / \mathrm{SR}}$ diastereomer, the invertomer ratio is $1: 3$; and for $2^{\mathrm{RR} / \mathrm{SS}}$, the invertomer ratio is $1: 30$ at room temperature (Figure 1 , SI p. S3-S23).
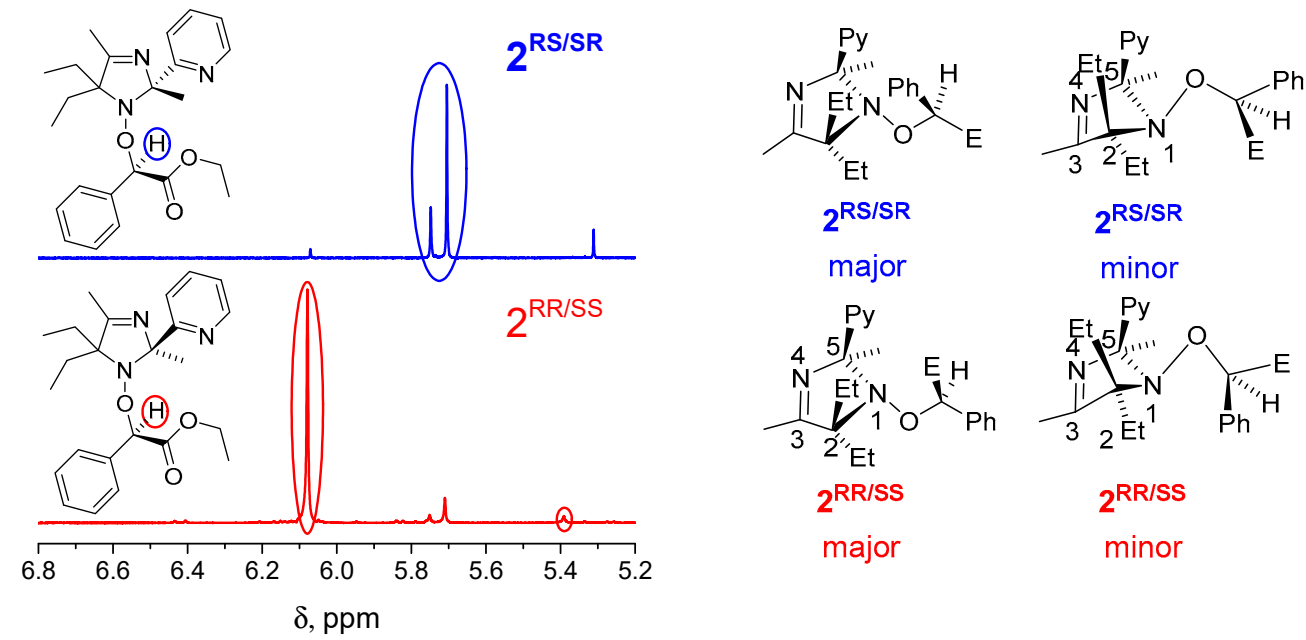

Figure 1. ${ }^{1} \mathrm{H}-\mathrm{NMR}$ spectra in the region of the proton at the tertiary chiral carbon center for the two diastereomers $2^{\mathrm{RS} / \mathrm{SR}}$ and $\mathbf{2}^{\mathrm{RR} / \mathrm{SS}}$. For each diastereomer, the highlighted regions correspond to the respective invertomers.

The nitrogen inversion rate constants were determined in the temperature range 265-311 K by 2D NOESY/Exchange Spectroscopy (EXSY) and at 302-331 K by Dynamic Nuclear Magnetic Resonance (DNMR) for the $2^{\mathrm{RS} / \mathrm{SR}}$ diastereomer, which was possible because of the substantial signal from its minor invertomer. Under such conditions, the nitrogen inversion is slow on the NMR time scale; plus, the alkoxyamine epimerization process is negligible and does not affect nitrogen inversion. The signals of protons at tertiary chiral carbon centers from DNMR and cross-peaks of the $\alpha$-pyridine protons from NOESY/EXSY (Figure 2; SI p. S180) were used.

In the case of NOESY/EXSY, the nitrogen inversion rate constant $k_{A B}$ is [42]:

$$
k_{A B}=\frac{K}{(K+1) \tau} \ln \frac{I_{A A}+K I_{B B}+(K+1) I_{\text {cross }}}{I_{A A}+K I_{B B}-(K+1) I_{\text {cross }}}
$$


where $K$ is the equilibrium constant; $\tau$-the mixing time (0.1 s); $I_{A A}$ and $I_{B B}$ 一the integral intensity of the diagonal peaks; $I_{\text {cross }}=\left(I_{A B}+I_{B A}\right) / 2$; and $I_{A B}$ and $I_{B A}$-the integral intensity of the cross peaks (Figure 2). For the DNMR line shape analysis, we used the DNMR5 software package [43].

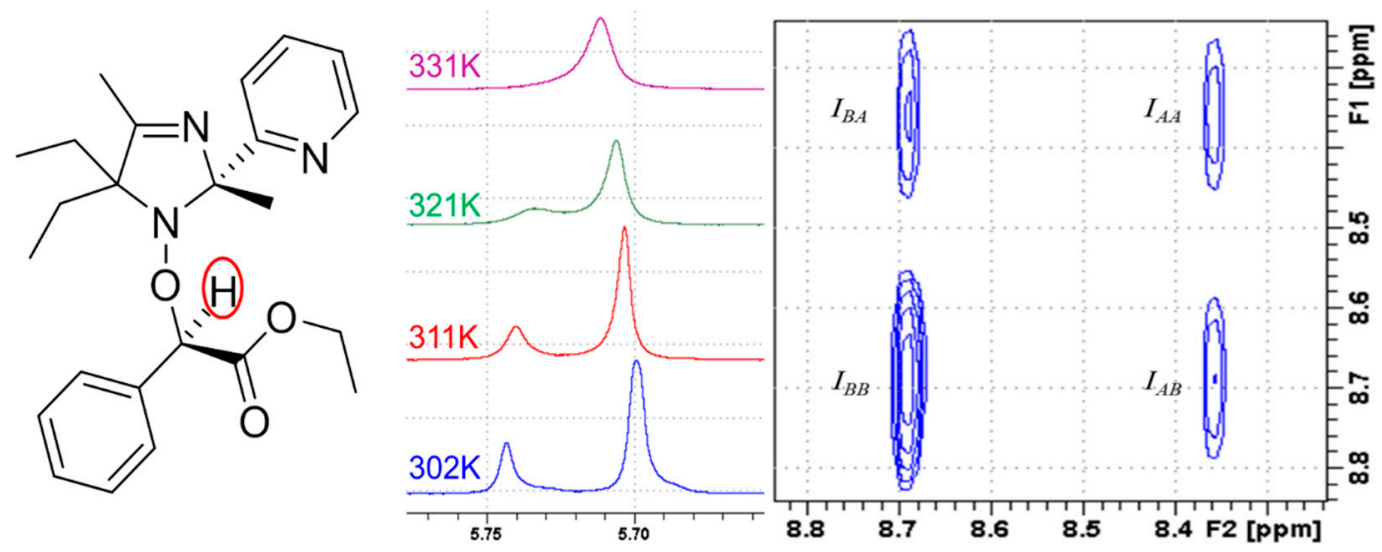

Figure 2. Center- ${ }^{1} \mathrm{H}$ DNMR spectra of $2^{\mathrm{RS} / \mathrm{SR}}$ at different temperatures. Right-fragment of the $2 \mathrm{D}$ NOESY/EXSY spectrum of $\mathbf{2}^{\mathbf{R S} / \mathbf{S R}}$ at $290 \mathrm{~K}$ showing the signals from the proton highlighted on the Left.

Enthalpy and entropy of activation were calculated using the Eyring equation:

$$
\Delta G^{\neq}=\Delta H^{\neq}-T \Delta S^{\neq}=-R T\left(\ln \left(k_{A B} / T\right)-\ln \left(k_{B} / h\right)\right)
$$

where $\Delta G^{\neq}, \Delta H^{\neq}$, and $\Delta S^{\neq}$are the Gibbs' free energy, enthalpy, and entropy of activation, respectively; $k_{A B}$-the nitrogen inversion rate constant; $k_{B}$-the Boltzmann constant; $h$-Planck's constant; and R-the universal gas constant (Figure 3, SI p. S180). The transmission coefficient was taken as 1.

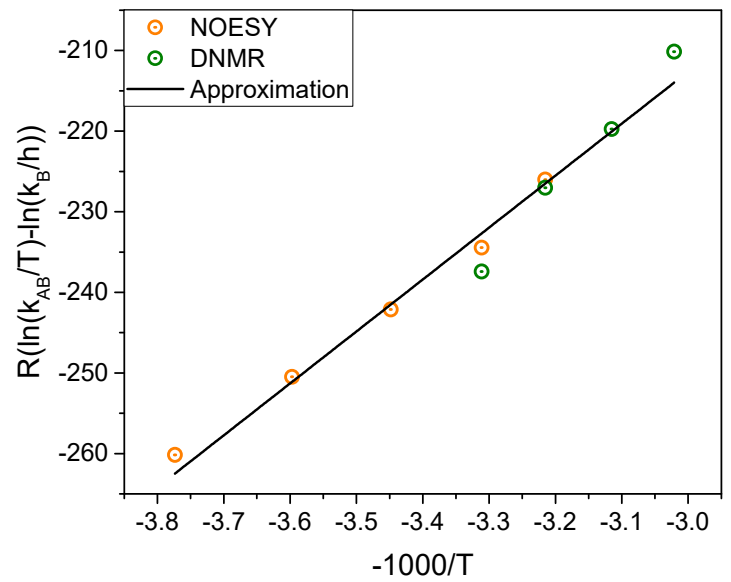

Figure 3. Eyring plot for the nitrogen inversion of the $2^{\mathbf{R S} / S R}$ diastereomer.

Determination of the nitrogen inversion rate constants for alkoxyamine 3 was performed in the temperature range $342-376 \mathrm{~K}$ by 2D NOESY/EXSY. The nitrogen inversion is much slower in 3 than in $2^{\text {RS/SR }}\left(0.086 / 0.36 \mathrm{~s}^{-1}\right.$ vs. $48 / 115 \mathrm{~s}^{-1}$ at $342 \mathrm{~K}$ in toluene- $\mathrm{d}_{8}$ for the rates of the more populated invertomer to/from the less populated invertomer). The ratio of isomers for nitrogen inversion in 3 is 4:1.

Due to the specific steric hindrances in alkoxyamines 2 and 3, nitrogen inversion is always accompanied by a rotation around the $\mathrm{N}-\mathrm{O}$ bond. The sequence of these two events could follow two alternative processes shown in Scheme 3a,b. However, according to DFT calculations (Figure 4, SI p. S205-S213), planarizing the $\mathrm{N}$-atom coordination center and the rotation of the $\mathrm{N}-\mathrm{O}$ bond do not occur sequentially. The two events are concerted, and the reaction path of nitrogen inversion contains 
no additional intermediates. The N-O-C fragment turns into the plane of the imidazoline ring in the transition state (TS). An introduction of bulky substituents to the carbon atom of this fragment would make TS less favorable and raise the energy barrier. The steric factor of a methyl group is greater than that of phenyl and especially of a hydrogen atom; therefore, nitrogen inversion in 3, which contains two methyl groups, should be slower than that in $2^{\text {RS/SR }}$.

(a)

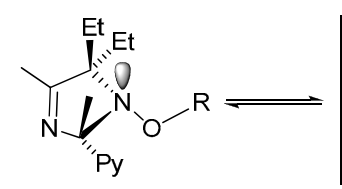

(b)<smiles>[R7]C1(CC)N=C(C)C(CC)C1OPCC</smiles>

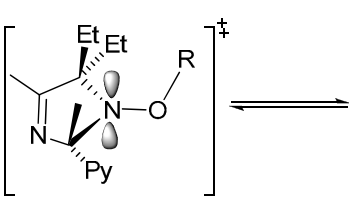

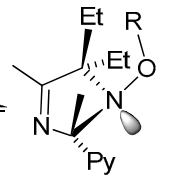<smiles>C=C</smiles><smiles>[R]ON1CCC1(P)N1ON=C(C)C1(P)CC</smiles>

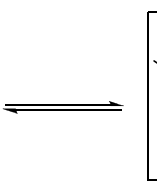

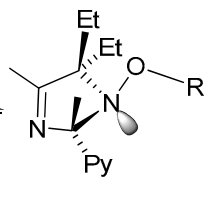

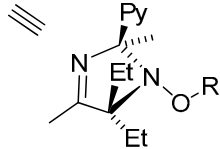
Et

Scheme 3. Process involving either (a) nitrogen inversion and $\mathrm{N}-\mathrm{O}$ bond rotation or (b) $\mathrm{N}-\mathrm{O}$ bond rotation and nitrogen inversion and expected transition state (TS) for the nitrogen inversion event.

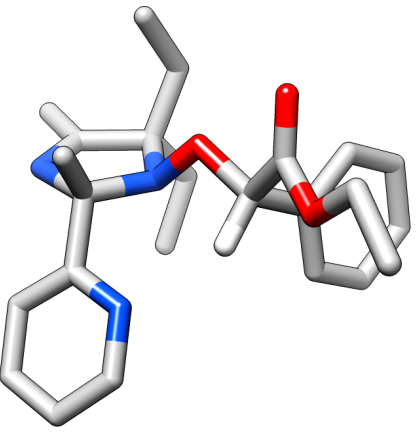

$2^{R S / S R}$

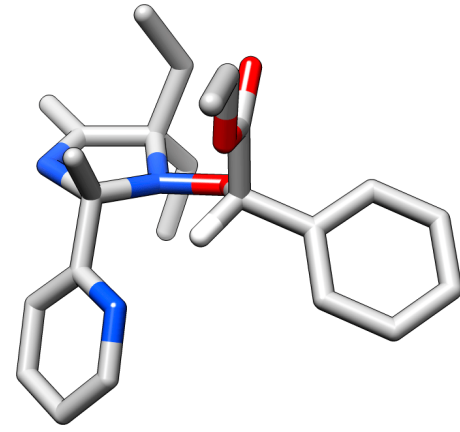

TS

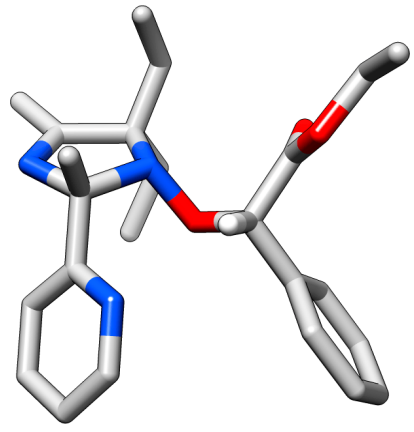

Invertomer of $2^{\text {RS/SR }}$

Figure 4. Geometries of the $2^{\mathrm{RS} / \mathrm{SR}}$ invertomers and the transition state of nitrogen inversion calculated by Density Functional Theory/Perdew-Birke-Ernzerhof (DFT/PBE)/ $\Lambda 01$.

\subsection{EPR Study of Alkoxyamines Homolysis}

Homolysis kinetics were investigated by EPR with oxygen as a scavenger for both diastereomers $2^{\text {RS/SR }}$ and $2^{\text {RR/SS }}$, as well as for alkoxyamine 3 . As expected, alkoxyamine $\mathbf{3}$ exhibited monoexponential kinetics; the homolysis rate constant was $k_{d}=2.5 \times 10^{-4} \mathrm{~s}^{-1}$ (Figure 5, green). In contrast, for alkoxyamines $2^{R S / S R}$ and $2^{R R / S S}$, bi-exponential kinetics were observed (Figure 5, blue and red), as evident in the upward deviation in concentration of nitroxide at short times. In general, such a dependence is typical of a mixture of diastereomers, such as a mixture of $2^{R S / S R}$ and $2^{R R / S S}$. However, the samples studied here contain only minor impurities of the corresponding diastereomers, which does not account for the deviations from monoexponential decay.

\subsection{NMR Study of Alkoxyamine Homolysis}

As mentioned above, the NMR experiments are affected by two dynamic processes in these alkoxyamines: (i) nitrogen inversion and (ii) homolysis of the $\mathrm{C}-\mathrm{ON}$ bond followed by recombination of the nitroxyl and alkyl radicals giving either of the two diastereomers (epimerization). The kinetics of homolysis can be observed by the addition of a radical scavenger to convert the generated radicals (or at least only the alkyl radicals) into diamagnetic products. The epimerization reaction relies on homolysis of the $\mathrm{C}-\mathrm{ON}$ bond to generate two radicals with a loss of chirality at both $\mathrm{N}$ - and $\mathrm{C}$-atoms, 
but chirality regenerates upon coupling. Thus, the $\Delta G^{\neq}$of epimerization should be close to the $\Delta G^{\neq}$of homolysis and larger than $110 \mathrm{~kJ} / \mathrm{mol}$. From the little data available in the literature concerning labile alkoxyamines [44,45], the $\Delta G^{\neq}$of nitrogen inversion is around $60-75 \mathrm{~kJ} / \mathrm{mol}$ for non-sterically hindered alkoxyamines and close to $\Delta G^{\neq}$of homolysis when sterically hindered [46].

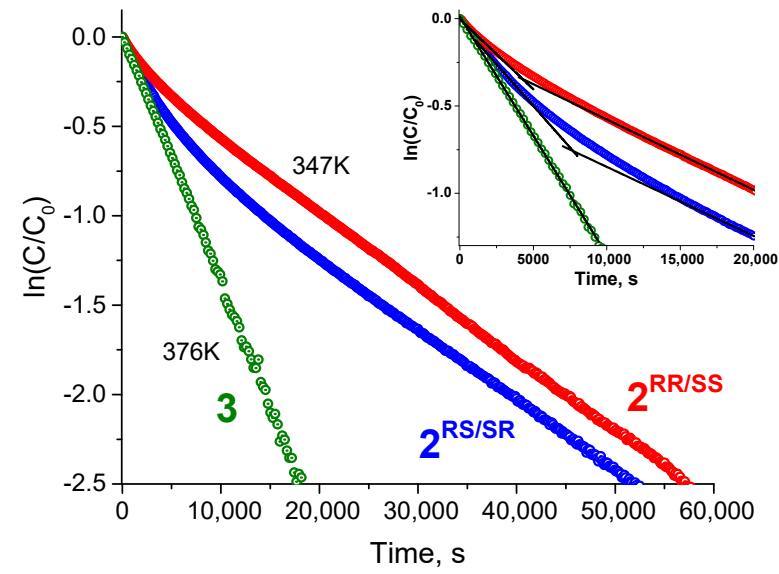

(a)

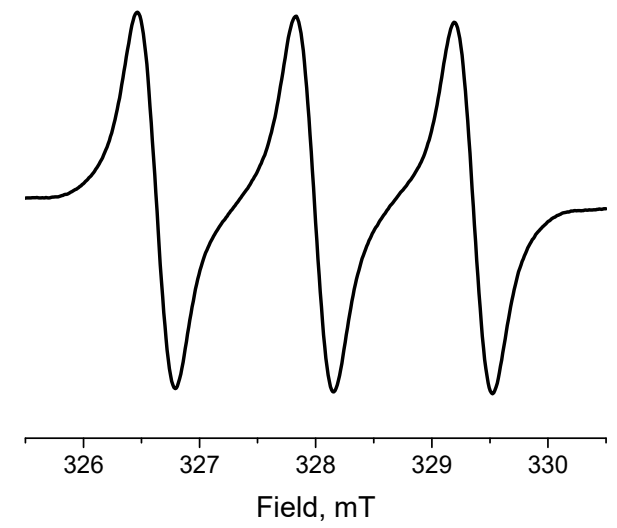

(b)

Figure 5. (a) Kinetic curves of alkoxyamine decomposition at semi-log scale of 3 at $376 \mathrm{~K}$ (green); $2^{\mathrm{RS} / \mathrm{SR}}$ (blue) and $2^{\mathrm{RR} / \mathrm{SS}}$ (red) at $347 \mathrm{~K}$ in toluene (left) measured using the second integral of EPR spectrum of formed radical $\mathbf{1}^{\bullet}$ (right); (b) EPR spectrum of formed radical $\mathbf{1}^{\bullet}$.

In ${ }^{1} \mathrm{H}-\mathrm{NMR}$ spectra, the signals of the $\alpha$-protons of pyridine moieties are easily recognized by the reduced spin-spin coupling constant with the neighboring proton $(\approx 5 \mathrm{~Hz})$ and are in the low-field region of the spectrum, not overlapping with the signals of other protons. Therefore, in reactions where the pyridine ring is not affected, the total integral of the entire region of $\alpha$-pyridine protons of the starting materials and products can be taken as unity and used as an "internal standard" in the processing of kinetic data. In addition, in reactions in which the nitroxide radical $\mathbf{1}^{\bullet}$ is the starting material or the product, the ${ }^{1} \mathrm{H}$ spectrum contains two relatively narrow, precisely integrable signals, $\delta=7.7$ and 8.9 ppm, with a half-width of about $20 \mathrm{~Hz}$ and each with an intensity of $1 \mathrm{H}$, which is presumably related to the pyridine fragment. The large chemical shifts difference of the ethyl group protons is noteworthy and is due to the specific spatial structure of this alkoxyamine (SI, p. S10).

\subsection{Homolysis of Alkoxyamines in the Absence of Scavengers (Epimerization)}

The main reaction upon heating of the alkoxyamine solution is the homolysis of the $\mathrm{C}-\mathrm{ON}$ bond with the formation of a nitroxyl and a planar alkyl radical with a subsequent recombination of these radicals to form one of the diastereomers. In the absence of any alkyl radical traps, including oxygen, the only one side reaction is a recombination of two alkyl radicals. It leads to the accumulation of an excess of the stable nitroxyl radical, forcing the recombination of nitroxyl and alkyl radical to be the main reaction occurring in our experimental conditions [36-38,47]. Toluene was chosen as the solvent after careful consideration of the NMR and EPR experiments, taking into account the advantage of using non-polar solvents in EPR experiments on the one hand and the typical activation energy of this reaction (and temperature range) on the other hand.

Kinetic data were collected for the proton located at the stereogenic carbon center (Figure 1). The kinetic scheme was the conventional reversible conversion $\mathbf{2}^{\mathbf{R S} / \mathbf{S R}} \rightleftarrows \mathbf{2}^{\mathbf{R R} / \mathrm{SS}}$ (Figure 6, Table 1). 

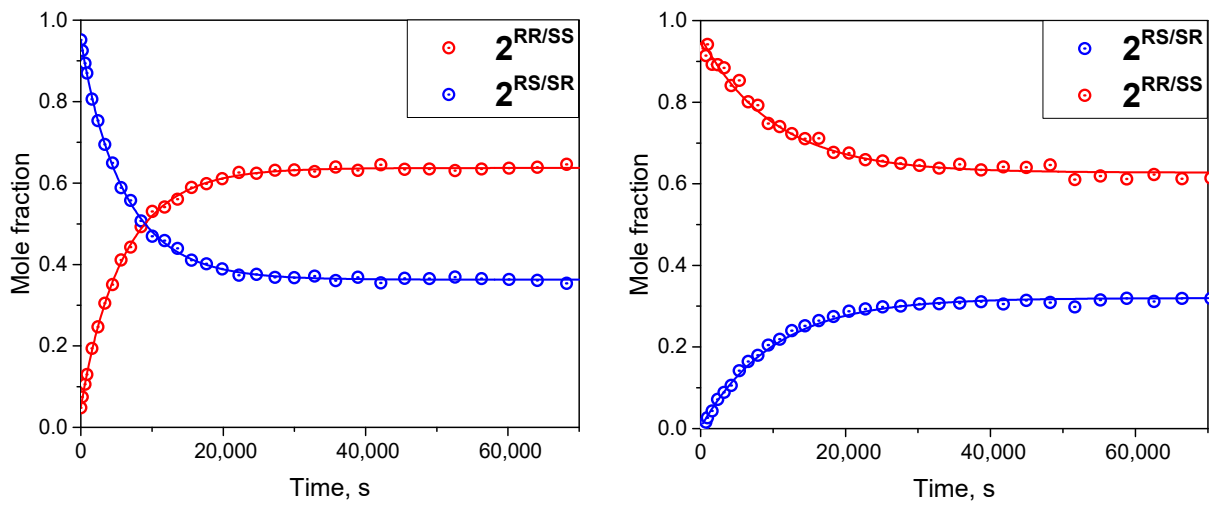

Figure 6. Kinetic curves for the epimerization reaction of alkoxyamines $2^{\mathrm{RS} / \mathrm{SR}}$ and $2^{\mathrm{RR} / \mathrm{SS}}$

Table 1. Rate constants $\left(\times 10^{-5} \mathrm{~s}^{-1}\right)$ for the reactions of alkoxyamines $(\approx 0.02 \mathrm{~mol} / \mathrm{L})$ with BME $(2 \mathrm{~mol} / \mathrm{L})$, $\mathrm{PhSH}(2 \mathrm{~mol} / \mathrm{L})$ and TEMPO $\left(3\right.$ eqv. $\left.{ }^{\mathrm{a}}\right)$ in toluene- $\mathrm{d}_{8}$ at $347 \mathrm{~K}$ by NMR.

\begin{tabular}{ccccc}
\hline & None & TEMPO & BME & PhSH \\
\hline $2^{\text {RS/SR }}$ & $10.5^{\mathrm{b}}$ & $5.0^{\mathrm{c}}$ & 8.3 & 16.3 \\
\hline $\mathbf{2}^{\text {RR/SS }}$ & $6.0^{\mathrm{b}}$ & $2.2^{\mathrm{c}}$ & 2.5 & 7.0 \\
\hline $\mathbf{3}$ & & $0.33^{\mathrm{c}}$ & $0.81^{\mathrm{d}}$ & $0.36^{\mathrm{e}}$ \\
\hline $\mathbf{1}^{\bullet}$ & & & 21 & $6400^{\mathrm{f}}$
\end{tabular}

a A lower concentration of TEMPO was essential to get resolved NMR spectra. ${ }^{b}$ Epimerization. ${ }^{\mathrm{c}}$ To simplify comparison of rate constants, the initial concentration of the substrate was taken as 1 . To obtain the formally correct value (as for bimolecular reaction with TEMPO), the rate constant must be divided by the initial concentration of 2 or $3(0.033 \mathrm{~mol} / \mathrm{L})$, see SI p. S189. ${ }^{\mathrm{d}}$ Interpolated to $347 \mathrm{~K}$ from the rates at $342 \mathrm{~K}$ and $376 \mathrm{~K}$ (the reaction was carried out at a different temperature so that broadening due to nitrogen inversion would be less disturbing). At $T=342 \mathrm{~K}$, $k=4.110^{-6} \mathrm{~s}^{-1} . T=376 \mathrm{~K}, k=3.110^{-4} \mathrm{~s}^{-1}$. e Extrapolated to $347 \mathrm{~K}$ from rate at $\mathrm{T}=376 \mathrm{~K}, k_{\mathrm{d}}=1.910^{-4} \mathrm{~s}^{-1}$. ${ }^{\mathrm{f}}$ Extrapolated to $347 \mathrm{~K}$ from the rates at $300 \mathrm{~K}$ by the Eyring equation with $\Delta S^{\#}=0$ (the reaction is very fast even at room temperature, incl. at increased speed is not measured).

For the calculation of the energetic parameters of the reaction, a number of experiments at different temperatures were performed (SI, p. S181-S186). The enthalpy and entropy of the reaction were obtained using:

$$
\Delta G_{0}=\Delta H_{0}-T \Delta S_{0}=-R T \ln K_{e q}
$$

where $K_{\text {eq }}$ is the equilibrium constant of the reaction. The calculated values are $\Delta H_{0}=0.021 \pm 0.046 \mathrm{~kJ} / \mathrm{mol}$ and $\Delta S_{0}=2.33 \pm 0.33 \mathrm{~J} / \mathrm{mol} / \mathrm{K}$. Since the equilibrium constant is practically independent of temperature, the enthalpy of the reaction is close to zero.

In addition, the enthalpy and entropy of activation were calculated for the epimerization reaction using the Eyring equation, in the same way as for nitrogen inversion. Energy parameters of $\Delta H^{\neq}=121.50 \pm 2.5 \mathrm{~kJ} / \mathrm{mol}$ and $\Delta S^{\neq}=29.6 \pm 6.2 \mathrm{~J} / \mathrm{mol} / \mathrm{K}$ (Figure 7) were obtained.

\subsection{Homolysis of Alkoxyamines in the Presence of Scavengers}

The decomposition of alkoxyamines $2^{\mathrm{RS} / \mathrm{SR}}, \mathbf{2}^{\mathrm{RR} / \mathrm{SS}}$, and $\mathbf{3}$ was studied in the presence of three different scavengers-TEMPO, PhSH, and BME.

Heating of $\mathbf{3}$ with TEMPO as an alkyl radical scavenger leads to a complete decomposition of the alkoxyamine (Scheme 4, SI p. S187, S188). TEMPO is not the best scavenger to use in such a case, as TEMPO-based alkoxyamines carrying a tertiary alkyl fragment with a functional group in general exhibit an $E_{\mathrm{a}}$ lower than $120 \mathrm{~kJ} / \mathrm{mol}[20]$. Here, TEMPO is efficient due to the H-abstraction from the tertiary alkyl radical converting it to an olefin [39]. The signals of the reaction products nitroxide $\mathbf{1}^{\bullet}$ and tert-butylmetacrylate 5 in stoichiometric amounts are present in the NMR spectra 
(SI p. S39-S43). The absence of signals of the hydroxylamine TEMPO-H in NMR is likely due to the

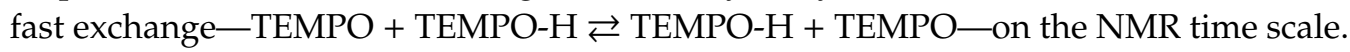

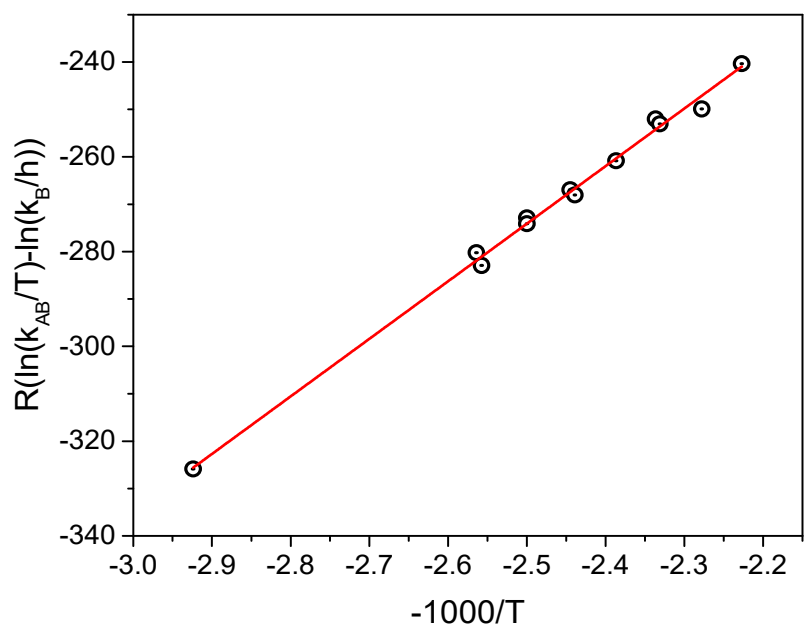

Figure 7. Eyring plot for epimerization reaction of $2^{\mathrm{RS} / \mathrm{SR}}$ diastereomer.<smiles></smiles><smiles>CC(C)ON1C(C)(C)CCCC1(C)O[Na]</smiles><smiles>CC(C)C(=O)OC(C)(C)C</smiles><smiles>CCCCCCCC</smiles><smiles>C=C(C)C(=O)OC(C)(C)C</smiles><smiles>CC(C)(C)ON1C(C)(C)CCCC1(C)C</smiles>

Scheme 4. The mechanism of decomposition of alkoxyamine 3 in the presence of TEMPO.

In sharp contrast to the results observed for 3 , the reaction of $\mathbf{2}^{\mathbf{R S} / \mathbf{S R}}$ with an excess of TEMPO at $347 \mathrm{~K}$ does not reach completion. Even when the experiment is performed at $367 \mathrm{~K}$ in the presence of TEMPO for $8 \mathrm{~h}$, decomposition is not complete, and an equilibrium is observed with the epimerization product $2^{\mathrm{RR} / \mathrm{SS}}$. Moreover, a steady-state is also observed between $\mathbf{2}^{\mathrm{RS} / \mathrm{SR}}+\mathbf{2}^{\mathrm{RR} / \mathrm{SS}}$ and the TEMPO-based alkoxyamine 6 (SI p. S44-S61). This additional equilibrium (Scheme 5) is established substantially faster than the epimerization of alkoxyamine 2 , its equilibrium constant being 0.3 .

Thus, when the $E_{\mathrm{a}}$ of TEMPO-based alkoxyamines is lower than that of the starting material, the use of TEMPO must comply with the requirement: the presence of a hydrogen at the carbon atom in the $\alpha$-position to the radical center in the released alkyl radical to favor the conversion of the latter into an olefin.

Unexpectedly, least-squares fitting of the kinetics data for the reversible reaction of $2^{\mathrm{RS} / \mathrm{SR}}$ with TEMPO revealed that the rate constants for the direct epimerization $2^{\mathrm{RS} / \mathrm{SR}} \rightleftarrows 2^{\mathrm{RR} / \mathrm{SS}}$ became significantly lower (SI, p. S189). In the presence of TEMPO, the diastereomers of $\mathbf{2}$ are transformed into each other via the intermediate formation of $\mathbf{6}$ only. Such unusual behavior could be explained by an unfavorable recombination of chiral $\mathbf{1}^{\bullet}$ and prochiral $7^{\bullet}$ in the opposite diastereomeric configuration, 
while still in the solvent cavity. Let us assume that the opposite diastereomer can be formed either in the cavity after reorientation of the radicals or after leaving the cavity. Although steric hindrances could prohibit reorientation in the cavity, free radical $7^{\bullet}$ out of the cavity would be rapidly scavenged by the more active TEMPO.

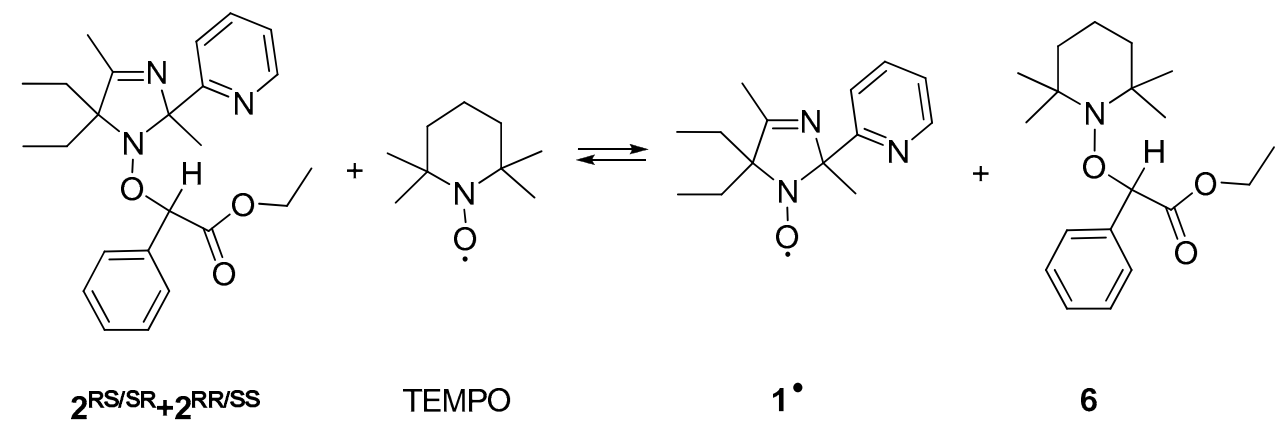

Scheme 5. The equilibrium between alkoxyamines 2 and TEMPO.

In the case of $\mathrm{PhSH}$ as a scavenger, monoexponential kinetics were observed (Figure 8) for 2 and 3 (SI p. S190-S193). In contrast to TEMPO, PhSH reduces the radicals $\mathbf{1}^{\bullet}, \mathbf{4}^{\bullet}$, and $\mathbf{7}^{\bullet}$ from the homolysis reaction, converting itself into diphenyldisulfide. As the result, alkyl radicals $4^{\bullet}$ and $7^{\bullet}$ would obtain an additional $\mathrm{H}$-atom from the scavenger, while nitroxide $\mathbf{1}^{\bullet}$ would be reduced mainly to the corresponding amine 8 (Scheme 6, SI p. S62-S91). The same amine is formed in the reduction of pure nitroxide $\mathbf{1}^{\bullet}$ with $\mathrm{PhSH}$, with a much faster rate (Table 1, SI p. S92-S113, S194). Additional minor products were also detected by NMR in the reaction mixtures, such as adducts of the nitroxide $\mathbf{1}^{\bullet}$ with the scavenger.

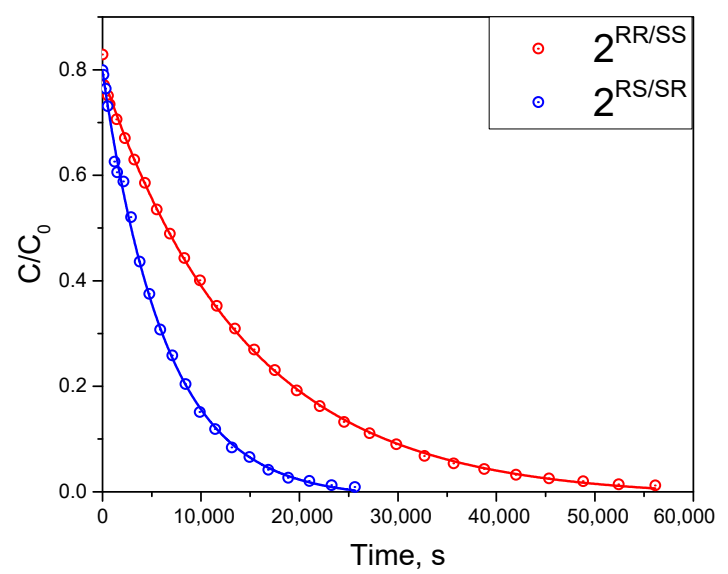

Figure 8. Kinetic curves of alkoxyamines decomposition of $2^{\mathrm{RS} / \mathrm{SR}}$ and $2^{\mathrm{RR} / \mathrm{SS}}$ at $347 \mathrm{~K}$ in toluene- $\mathrm{d}_{8}$ in the presence of spin trap PhSH.

When BME was used as the radical scavenger, bi-exponential kinetics were observed for alkoxyamines $\mathbf{2}^{\mathbf{R S} / \mathbf{S R}}$ and $\mathbf{2}^{\mathrm{RR} / \mathrm{SS}}$ (Figure 9), and $\mathbf{3}$ (SI p. S195-S197). For $\mathbf{2}^{\mathbf{R S} / \mathbf{S R}}$ and $\mathbf{2}^{\mathbf{R R} / \mathbf{S S}}$, the decay was fit with a 4-reaction kinetic scheme:

$$
\begin{array}{ll}
2^{\mathrm{RS} / \mathrm{SR}} \rightarrow 2^{\mathrm{RR} / \mathrm{SS}} & \mathrm{k}_{\mathrm{AB}} \\
2^{\mathrm{RR} / \mathrm{SS}} \rightarrow 2^{\mathrm{RS} / \mathrm{SR}} & \mathrm{k}_{\mathrm{BA}} \\
2^{\mathrm{RS} / \mathrm{SR}} \rightarrow \text { Products } & \mathrm{k}_{\mathrm{AP}} \\
2^{\mathrm{RR} / \mathrm{SS}} \rightarrow \text { Products } & \mathrm{k}_{\mathrm{BP}}
\end{array}
$$


where $\mathrm{k}_{\mathrm{AB}}, \mathrm{k}_{\mathrm{BA}}$ are the epimerization rate constants for the two diastereomers; and $\mathrm{k}_{\mathrm{AP}}, \mathrm{k}_{\mathrm{BP}}$ are the rate constants of the reactions of each diastereomer with $\mathrm{BME}$. To solve the kinetic equations, we assume relationships $\mathrm{K}=\mathrm{k}_{\mathrm{AB}} / \mathrm{k}_{\mathrm{BA}}$ and $\mathrm{k}_{\mathrm{P}}=\mathrm{k}_{\mathrm{AP}} / \mathrm{k}_{\mathrm{BP}}$ and obtained the constants $($ at $347 \mathrm{~K}): \mathrm{k}_{\mathrm{AB}}=(8.29 \pm 0.58)$ $\times 10^{-5} \mathrm{~s}^{-1}, \mathrm{~K}=1.33 \pm 0.2, \mathrm{k}_{\mathrm{AP}}=(8.27 \pm 6.1) \times 10^{-5} \mathrm{~s}^{-1}$, and $\mathrm{k}_{\mathrm{P}}=3.25 \pm 0.75$.<smiles>[CH2]C(=O)C(C)OC(C)(C)C</smiles>

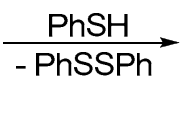$$
10
$$

$7^{\bullet}$
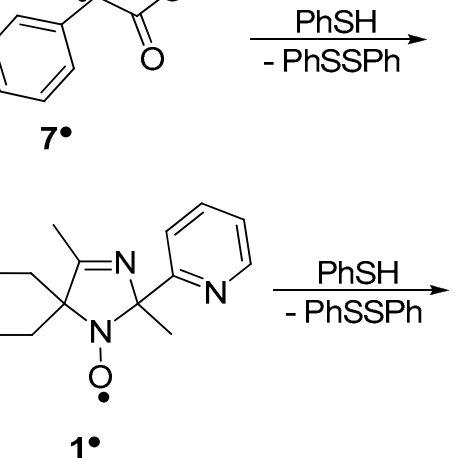<smiles>CC(C)C(=O)OC(C)(C)C</smiles>

4<smiles>CCOC(=O)Cc1ccccc1</smiles>

\section{7}<smiles>CCC1(CC)NC(C)(c2ccccn2)N=C1C</smiles>

8

Scheme 6. Decomposition of alkoxyamines $2^{\text {RS/SR }}$ and 3 in the presence of $\mathrm{PhSH}$.

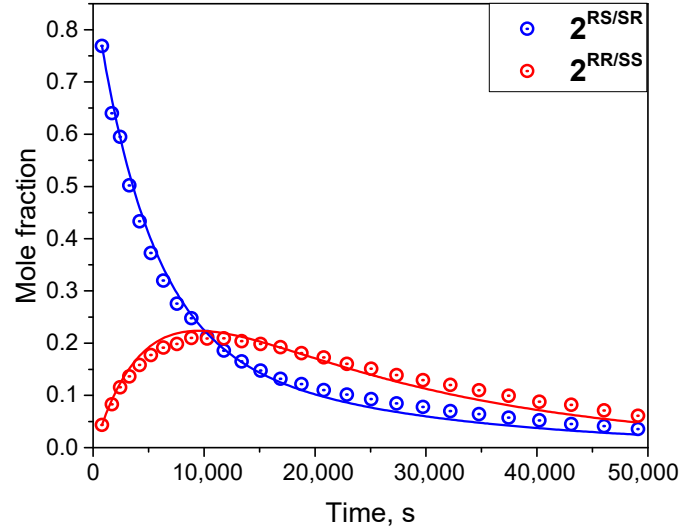

(a)

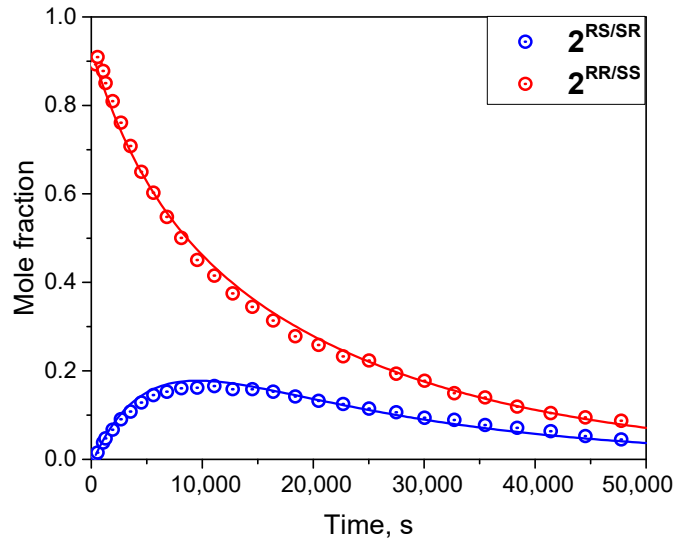

(b)

Figure 9. Kinetic curves for decomposition of $2^{\mathrm{RS} / \mathrm{SR}}$ and $\mathbf{2}^{\mathrm{RR} / \mathrm{SS}}$ at $347 \mathrm{~K}$ in toluene- $\mathrm{d}_{8}$ in the presence of spin trap BME. (a) Initial mole fraction of $\mathbf{2}^{\mathbf{R S} / \mathbf{S R}}$ is equal to 1 while of $\mathbf{2}^{\mathbf{R R} / \mathbf{S S}}$ is equal to zero. (b) Initial mole fraction of $2^{\mathrm{RR} / \mathrm{SS}}$ is equal to 1 while of $2^{\mathrm{RS} / \mathrm{SR}}$ is equal to zero.

Our numerous experiments on the destruction kinetics of the alkoxyamines in the presence of BME showed several contradicting but systematically reproducible features which were not observed either with PhSH or with TEMPO (Table 1).

- The rate constants for the reaction of $2^{\mathbf{R S} / S R}$ and $2^{\mathbf{R R} / \mathrm{SS}}$ with $\mathrm{PhSH}$ are slightly higher than the rate constants for their epimerization. This is not surprising and can be explained by the influence of the different medium with a large excess of the spin trap. In contrast, the rate constants for the reaction of $2^{\mathbf{R S} / S R}$ and especially of $2^{\mathbf{R R} / S S}$ with BME are substantially lower than the epimerization rate constants. 
- In contrast to the behavior of $2^{\mathrm{RS} / \mathrm{SR}}$ and $2^{\mathrm{RR} / \mathrm{SS}}$ (see item above), the rate constant for the reaction of 3 with BME is significantly higher than rate constant for its reaction with PhSH.

- Quite unexpected is the much lower reactivity of $2^{\mathrm{RR} / \mathrm{SS}}$ with BME in comparison with its diastereomer $2^{\mathbf{R S} / S R}$. It can hardly be explained by steric differences in the substrates: the starting diastereomers have very similar energies, and the transition states should be close to the corresponding alkyl and nitroxide radicals, which are identical for both diastereomers.

- The decay rates of the alkoxyamines monotonically increase with increasing BME concentration but do not reach a plateau even at a 100-fold excess of BME.

These unexpected results clearly point out that the reactions of alkoxyamines with $\mathrm{PhSH}$ and BME have different mechanisms. It may even be possible that BME reacts with alkoxyamines without a preceding homolysis step. This supposition forced us to perform a thorough NMR study on the products formed in the decomposition of $\mathbf{2}^{\mathrm{RS} / \mathrm{SR}}, \mathbf{3}$, and $\mathbf{1}^{\bullet}$ in the presence of BME. The structures and the complete NMR signal assignments for all the main components of the reaction mixtures, including assignments for nuclei that differ from each other only in their spatial configuration, were unambiguously determined by $2 \mathrm{D}$ NMR (HSQC, HMBC, ${ }^{1} \mathrm{H}_{-}{ }^{15} \mathrm{~N}$ HMBC, COSY, NOESY, and DOSY); see SI.

Decay of $2^{\text {RS/SR }}$ and $2^{\mathrm{RR} / \mathrm{SS}}$ with an excess of BME afforded products analogous to those of the reaction with $\mathrm{PhSH}$. However, the reaction with BME proceeds much less selectively (SI p. S114-S138). The alkyl radical $7^{\bullet}$ formed by decomposition of the alkoxyamine tends to disproportionate, giving the expected ethyl-2-phenylacetate 7 along with oxidized forms 9 and $\mathbf{1 0}$ (7:9:10 =1:0.7:0.9) (Chart 2). The nitroxide radical $\mathbf{1}^{\circ}$, as in the case of $\mathrm{PhSH}$, was mainly reduced to the corresponding amine 8 along with minor adducts with BME. Similar adducts of nitroxide radicals with thiols were reported earlier [48]. Surprisingly, a substantial additional product 1,3-dimethylimidazo [1,5-a]pyridine $\mathbf{1 1}$ was detected in the reaction mixture (8:adducts:11 = 1:0.6:0.5). The heterocyclic skeleton of $\mathbf{1 1}$ is completely different from that of the original alkoxyamine (Chart 2), and even traces of this heterocycle were not observed after the homolysis of 2 with PhSH.

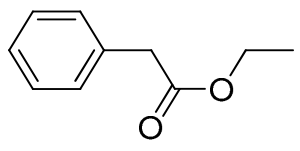

7<smiles>CCC1(CC)NC(C)(c2ccccn2)N=C1C</smiles>

8

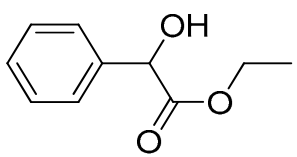

9

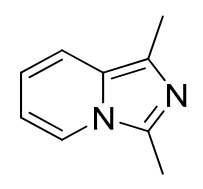

11

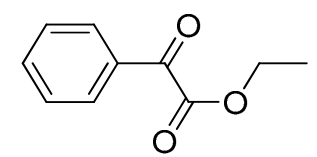

10

Chart 2. Structures of $7,8,9,10,11$.

For the case of decay of alkoxyamine 3 in the presence of BME, tert-butylisobutyrate 4 and amine 8 were also detected in the reaction mixture, as expected. However, the main products of alkoxyamine decay were now the same heterocycle 11, which was already observed in the case of $\mathbf{2}^{\mathrm{RS} / \mathrm{SR}}$ and $\mathbf{2}^{\mathrm{RR} / \mathrm{SS}}$, and tert-butyl-2-methyl-2-(pentan-3-ylideneaminooxy)propanoate $\mathbf{1 2}(\mathbf{1 1 , 1 2 : 4 , 8}=1$ :0.6) (Chart 3, SI p. S139-S157). It is important to note that the structure of product 12 precludes every mechanism proceeding through homolysis of the substrate to alkyl and nitroxide radicals. Oxime ether 12 can be formed only through rearrangement of the original alkoxyamine 3 . A minor amount of diethylketone 13 was additionally observed, which originated apparently from oxime ether $\mathbf{1 2}$. 


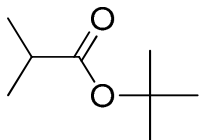

4

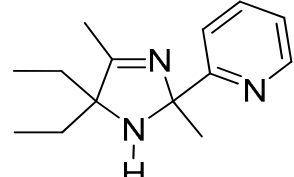

8<smiles>Cc1nc(C)n2ccccc12</smiles>

11

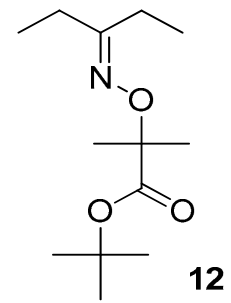

2

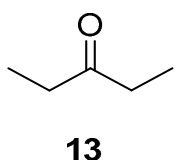

Chart 3. Structures of $4,8,11,12,13$.

A small amount of compound 11 and diethylketone $\mathbf{1 3}(10 \%)$ were detected even in the reaction of nitroxide $\mathbf{1}^{\bullet}$ with BME, along with the expected major reduction products (SI p. S158-S179, S198). An analogous product mixture was also observed after the thermolysis of alkoxyamines at $150{ }^{\circ} \mathrm{C}$ in DMSO or o-dichlorobenzene in the absence of scavengers (SI, p. S199).

Apparently, the essential side reaction of either alkoxyamine $\mathbf{2}$ or $\mathbf{3}$, or nitroxide $\mathbf{1}^{\bullet}$ with BME breaks the imidazoline ring followed by cyclization with the nitrogen of the pyridine residue. The mechanism of this unexpected rearrangement will be the subject of a more detailed study in the future. However, it is clear that this side reaction complicates the reaction mixtures and significantly shifts the numeric results of kinetics measurements. Instead of the expected alkoxyamine homolysis kinetics, the data reflect some aggregate of parallel homolysis and heterocyclic rearrangement under the influence of BME.

Hence, the choice of scavenger is crucial for a reliable and accurate estimate of the true homolysis rate constant.

Thus, the upward deviation in EPR kinetics obtained with a less efficient scavenger is ascribed to the time needed to reach a pseudo-equilibrium in the reaction. Then, after this pseudo-equilibrium is reached, a mono exponential decay is observed. When the experiment is performed in the presence of a really efficient radical scavenger, free of side processes, such as PhSH (vide infra), a mono-exponential decay in ${ }^{1} \mathrm{H}$ NMR and a mono-exponential nitroxide growth in EPR provide the same rate constant as expected.

\section{Experimental}

Routine ${ }^{1} \mathrm{H}$ and ${ }^{13} \mathrm{C}-\mathrm{NMR}$ spectra were recorded on Bruker AV-300, AV-400, and DRX-500 instruments. The structures, including spatial structure, and the complete NMR signal assignments of alkoxyamines and their decomposition products were determined by 2D NMR (COSY, HSQC, HMBC, ${ }^{1} \mathrm{H}^{15} \mathrm{~N}$ HMBC, NOESY, ROESY, and DOSY) on a Bruker Avance-III 600 instrument at $600.30 \mathrm{MHz}$, $150.96 \mathrm{MHz}$ and $60.85 \mathrm{MHz}$ for ${ }^{1} \mathrm{H},{ }^{13} \mathrm{C}$ and ${ }^{15} \mathrm{~N}$, respectively. Chemical shifts were measured for ${ }^{1} \mathrm{H}$ and ${ }^{13} \mathrm{C}$ relative to the residual signals of solvents $\left(\mathrm{CDCl}_{3}: \delta_{\mathrm{H}} 7.24 \mathrm{ppm}, \delta_{\mathrm{C}} 76.9 \mathrm{ppm}\right.$; toluene-d8: $\delta_{\mathrm{H}} 2.13 \mathrm{ppm}, \delta_{\mathrm{C}} 20.1 \mathrm{ppm}$; DMSO: $\delta_{\mathrm{H}} 2.51 \mathrm{ppm}$ ), and for ${ }^{15} \mathrm{~N}$ relative to an external $\mathrm{NH}_{3}$ standard $\left(\delta_{\mathrm{N}}=0 \mathrm{ppm}\right)$.

IR spectra were acquired on an FTIR spectrometer in $\mathrm{KBr}$ or neat and are reported in wavenumbers $\left(\mathrm{cm}^{-1}\right)$. Reactions were monitored by TLC using UV light $(254 \mathrm{~nm})$ and/or aqueous permanganate for visualization. Column chromatography was performed on silica gel 60, (70-230 Mesh).

\section{Synthesis (Scheme 7)}

5,5-Diethyl-2,4-dimethyl-2-(pyridin-2-yl)-2,5-dihydro-1H-imidazol 1-oxyl (1•). Synthesis was in analogy to the literature procedures [49]. To a stirred solution of 3-hydroxylamino-3-ethylpentan-2-one hydrochloride (14; $2.50 \mathrm{~g}, 13.8 \mathrm{mmol})$ in $\mathrm{MeOH}(20 \mathrm{~mL})$, ammonia acetate $(3.18 \mathrm{~g}, 41.3 \mathrm{mmol})$ and 2-acetylpyridine $(1.87 \mathrm{~g}, 15.1 \mathrm{mmol})$ were added. The reaction mixture was stirred at $+60^{\circ} \mathrm{C}$ for $4 \mathrm{~h}$; then, it was cooled to room temperature and allowed to stand overnight. Then, the mixture was diluted with $20 \mathrm{~mL}$ of $\mathrm{H}_{2} \mathrm{O}$ and kept at $-10{ }^{\circ} \mathrm{C}$ overnight. A crystalline precipitate of 5,5-diethyl-2,4-dimethyl2-(pyridin-2-yl)-2,5-dihydro-1H-imidazol 1-ol (15) was filtered off and washed with cold $\mathrm{H}_{2} \mathrm{O}$. To a stirred 
suspension of 15 in $\mathrm{CHCl}_{3}(25 \mathrm{~mL}), \mathrm{MnO}_{2}(7 \mathrm{~g}, 80.5 \mathrm{mmol})$ was added portion-wise. After the reaction was complete (monitored by TLC analysis; $\mathrm{CHCl}_{3}+\mathrm{CH}_{3} \mathrm{OH}$ 20:1), the manganese oxides were filtered off, and the solvent was removed in vacuum to yield radical 1• as a yellow crystals.

5,5-diethyl-2,4-dimethyl-2-(pyridin-2-yl)-2,5-dihydro-1H-imidazol 1-ol (15): Yield 60\%, colorless crystals, m.p. $187{ }^{\circ} \mathrm{C}$ (decomp.). ${ }^{1} \mathrm{H}-\mathrm{NMR}\left(400 \mathrm{MHz}, \mathrm{CDCl}_{3}+\mathrm{CD}_{3} \mathrm{OD}\right): \delta=0.61\left(\mathrm{t}, 3 \mathrm{H}, J=7.32 \mathrm{~Hz}, \mathrm{CH}_{3}\right)$, $1.01\left(\mathrm{t}, 3 \mathrm{H}, \mathrm{J}=7.44 \mathrm{~Hz}, \mathrm{CH}_{3}\right), 1.50\left(\mathrm{~m}, 1 \mathrm{H}, \mathrm{CH}_{2}\right), 1.59\left(\mathrm{~m}, 1 \mathrm{H}, \mathrm{CH}_{2}\right), 1.71\left(\mathrm{~m}, 1 \mathrm{H}, \mathrm{CH}_{2}\right), 1.73\left(\mathrm{~s}, 3 \mathrm{H}, \mathrm{CH}_{3}\right)$, $1.99\left(\mathrm{~m}, 1 \mathrm{H}, \mathrm{CH}_{2}\right), 2.02\left(\mathrm{~s}, 3 \mathrm{H}, \mathrm{CH}_{3}\right), 4.35(\mathrm{~s}, 1 \mathrm{H}, \mathrm{OH}), 7.23(\mathrm{~m}, 1 \mathrm{H}, \mathrm{Py}), 7.60(\mathrm{~m}, 1 \mathrm{H}, \mathrm{Py}), 7.73(\mathrm{~m}, 1 \mathrm{H}, \mathrm{Py})$, 8.51 (m, 1H, Py). ${ }^{13} \mathrm{C}-\mathrm{NMR}\left(100 \mathrm{MHz}, \mathrm{CDCl}_{3}+\mathrm{CD}_{3} \mathrm{OD}\right): \delta=8.85\left(\underline{\mathrm{CH}}_{3} \mathrm{CH}_{2}\right), 10.74\left(\mathrm{CH}_{3} \mathrm{CH}_{2}\right), 26.64$ $\left(\mathrm{CH}_{3} \underline{\mathrm{CH}}_{2}\right), 30.26\left(\mathrm{CH}_{3} \mathrm{CH}_{2}\right), 80.86\left(\underline{\mathrm{CEt}}_{2}\right), 95.11(\mathrm{NCN}), 121.43,122.88(\underline{\mathrm{CH}}, 3-\mathrm{Py}$ and 5-Py), $137.66(\underline{\mathrm{CH}}, 4-\mathrm{Py}), 148.54 \quad(\underline{\mathrm{CH}}, 6$ 6-Py), $165.50 \quad(\underline{\mathrm{C}} \mathrm{H}, 2-\mathrm{Py}), 177.85 \quad(\underline{\mathrm{C}}=\mathrm{N}) . \quad \mathrm{UV}$ (EtOH): $\lambda_{\max }(\log \varepsilon)=260$ (3.99). IR (neat): 756, 795, 991, 1043, 1095, 1352, 1385, 1431, 1462, 1568, 1581, 1651, 2877, 2904, 2966, 2995, 3047, $3144 \mathrm{~cm}^{-1}$. Anal. calcd. for $\mathrm{C}_{14} \mathrm{H}_{21} \mathrm{~N}_{3} \mathrm{O}: \mathrm{C}, 67.98 ; \mathrm{H}, 8.56 ; \mathrm{N}$, 16.99; found: C, 68.26; H, 8.45; N, 16.93 .

5,5-Diethyl-2,4-dimethyl-2-(pyridin-2-yl)-2,5-dihydro-1H-imidazol 1-oxyl (1•): Yield 90\%, yellow crystals, m.p. $51-52{ }^{\circ} \mathrm{C}$ (hexane). UV (EtOH): $\lambda \max (\log \varepsilon)=260$ (3.57). IR (neat): 754, 787, 876, 924, 997, 1049, 1095, 1146, 1178, 1257, 1300, 1358, 1387, 1433, 1462, 1572, 1587, 1641, 2879, 2937, 2964, 2978, $3059 \mathrm{~cm}^{-1}$. Anal. calcd. for $\mathrm{C}_{14} \mathrm{H}_{20} \mathrm{~N}_{3} \mathrm{O}: \mathrm{C}, 68.26 ; \mathrm{H}, 8.18 ; \mathrm{N}, 17.06$; found: $\mathrm{C}, 68.46 ; \mathrm{H}, 8.23 ; \mathrm{N}, 17.25$. ${ }^{1} \mathrm{H}-\mathrm{NMR}$ spectrum (600 MHz): SI, p S24. EPR spectrum: SI, p S217; hyperfine coupling $1.351 \mathrm{mT}$, $\mathrm{g}=2.00608$.

Synthesis of alkoxyamines 2 and 3 (General procedure). The alkoxyamines were prepared using the method developed by Matyjaszewski et al. [50] (Scheme 7). A mixture of the nitroxide 1• (2.2 mmol), 2-bromo-2-methylpropionic acid tert-butyl ester (2.25 mmol) or 2-bromo-2-phenylacetatic acid ethyl ester ( $2.25 \mathrm{mmol})$, Cu powder (140 mg, $2.25 \mathrm{mmol}), 4,4^{\prime}$-di-tert-butyl-2,2'-bipyridine ( $\left.24 \mathrm{mg}, 0.09 \mathrm{mmol}\right)$, $\mathrm{Cu}(\mathrm{OTf})_{2}(8 \mathrm{mg}, 0.023 \mathrm{mmol})$, and benzene $(5 \mathrm{~mL})$ was placed into a Schlenk flask and degassed by three freeze-pump-thaw cycles. The solution was stirred for $24 \mathrm{~h}$ at $50^{\circ} \mathrm{C}$. Benzene was removed in vacuum, and the residue was separated by column chromatography (silica gel, hexane-diethyl ether 1:6 for 2 and hexane-ethyl acetate 2:1 for 3).

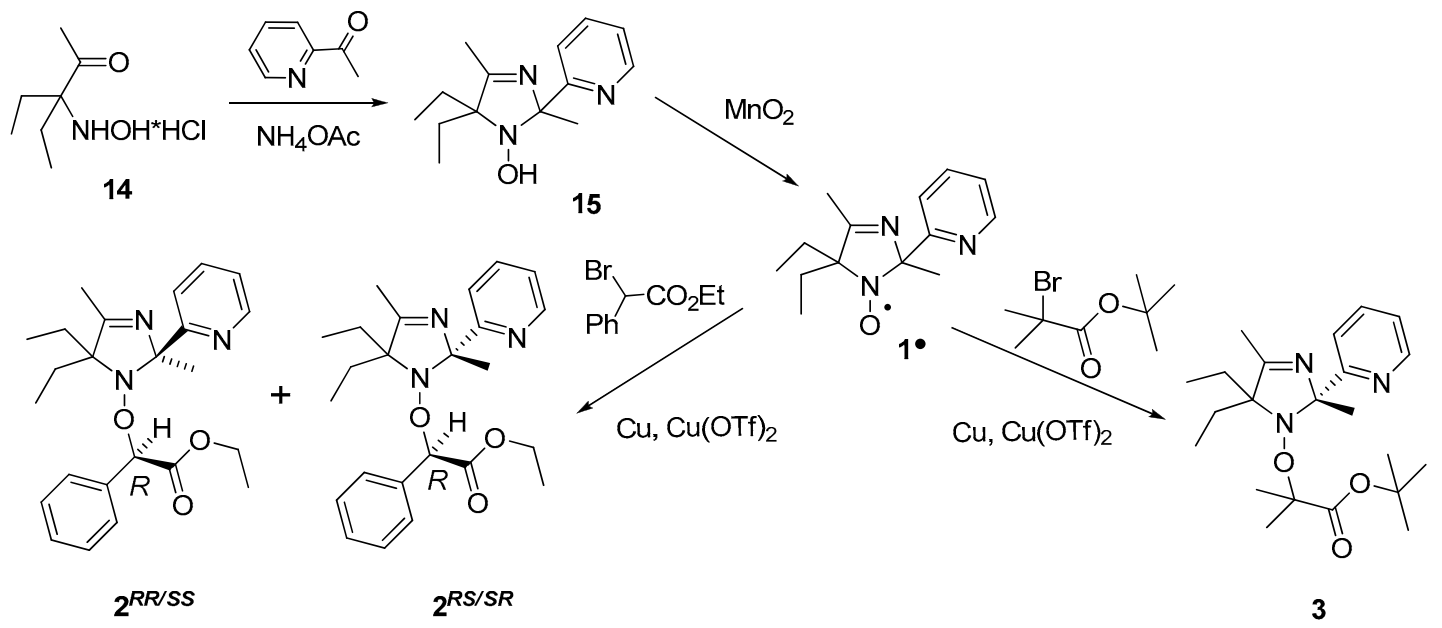

Scheme 7. Synthesis of alkoxyamines 2 and 3.

(R,R)-Ethyl-2-(5,5-diethyl-2,4-dimethyl-2-(pyridin-2-yl)-2,5-dihydro-1H-imidazol-1-yloxy)-2-phenylacetate $\left(2^{\mathrm{RR} / \mathrm{SS}}\right)$ : Yield 30\%, colorless oil. ${ }^{1} \mathrm{H}-\mathrm{NMR}\left(400 \mathrm{MHz}^{\mathrm{CDCl}} \mathrm{CDC}_{3}\right): \delta=0.37\left(\mathrm{t}, 3 \mathrm{H}, J=7.3 \mathrm{~Hz} \mathrm{CH}_{3}\right)$, $1.04\left(\mathrm{t}, 3 \mathrm{H}, J=7.3 \mathrm{~Hz} \mathrm{CH}_{3}\right), 1.12\left(\mathrm{t}, 3 \mathrm{H}, J=7.3 \mathrm{~Hz}, \mathrm{CH}_{3}\right), 1.48\left(\mathrm{ABq}, 1 \mathrm{H}, J=7.3,14 \mathrm{~Hz}_{\mathrm{C}} \mathrm{CH}_{2}\right)$, $1.67\left(\mathrm{ABq}, 1 \mathrm{H}, J=7.3,14 \mathrm{~Hz}, \mathrm{CH}_{2}\right), 1.73\left(\mathrm{~s}, 3 \mathrm{H}, \mathrm{CH}_{3}\right), 1.81\left(\mathrm{ABq}, 1 \mathrm{H}, J=7.3,14 \mathrm{~Hz}, \mathrm{CH}_{2}\right), 1.98\left(\mathrm{~s}, 3 \mathrm{H}, \mathrm{CH}_{3}\right)$, 
$2.47\left(\mathrm{ABq}, 1 \mathrm{H}, J=7.3,14 \mathrm{~Hz}, \mathrm{CH}_{2}\right), 3.97\left(\mathrm{ABq}, 1 \mathrm{H}, J=7.0,17.9 \mathrm{~Hz}, \mathrm{CH}_{2}-\mathrm{O}\right), 4.10(\mathrm{ABq}, 1 \mathrm{H}, J=7.0$, $\left.17.9 \mathrm{~Hz}, \mathrm{CH}_{2}-\mathrm{O}\right), 6.04(\mathrm{~s}, 1 \mathrm{H}, \mathrm{C} \underline{\mathrm{H}}-\mathrm{Ph}), 7.11-7.15(\mathrm{~m}, 1 \mathrm{H}, \mathrm{Py}), 7.30-7.37(\mathrm{~m}, 3 \mathrm{H}, \mathrm{Ph}), 7.38-7.41(\mathrm{~m}, 1 \mathrm{H}$, Py), 7.49-7.54 (m, 2H, Ph), 7.55-7.59 (m, 1H, Py), 8.64-8.68 (m, 1H, Py). 13C NMR ( $\left.\mathrm{CDCl}_{3}, 125 \mathrm{MHz}\right)$ : $\delta=8.75,10.79\left(2 * \mathrm{CH}_{3}, \mathrm{Et}\right), 13.88\left(\mathrm{CH}_{3}, \mathrm{EtO}\right), 16.63\left(\mathrm{CH}_{3}-\mathrm{CNN}\right), 23.59\left(\mathrm{CH}_{3}-\mathrm{C}=\mathrm{N}\right), 27.17,29.71\left(2^{*} \mathrm{CH}_{2}\right.$, $\mathrm{Et}), 60.29\left(\mathrm{CH}_{2}, \mathrm{EtO}\right), 82.01\left(\underline{\mathrm{CEt}}_{2}\right), 83.32$ ( $\left.\underline{\mathrm{CH}}-\mathrm{O}-\mathrm{N}\right), 96.87\left(\mathrm{Py}-\underline{\mathrm{C}}-\mathrm{CH}_{3}\right), 119.91,121.55,127.45,128.19$, 128.29 (Ar), 135.47 (CH, 4-Py), $135.60\left({ }^{i} \mathrm{Ph}\right), 148.58(\mathrm{CH}, 2-\mathrm{Py}), 164.82\left({ }^{i} \mathrm{Py}\right), 172.51(\mathrm{C}=\mathrm{O}), 174.25(\mathrm{C}=\mathrm{N})$. $\mathrm{UV}(\mathrm{EtOH}): \lambda_{\max }(\log \varepsilon)=256(4.28) . \mathrm{IR}($ neat): 623, 696, 750, 789, 1063, 1095, 1180, 1205, 1273, 1375, 1431, 1454, 1468, 1587, 1664, 1747, 2875, 2935, 2962. Anal. calcd. for $\mathrm{C}_{24} \mathrm{H}_{31} \mathrm{~N}_{3} \mathrm{O}_{3}$ : C, 70.39; $\mathrm{H}, 7.63$; $\mathrm{N}, 10.26$; found: C, 70.49; H, 7.58; N, 10.18. NMR assignments (600 MHz): SI, p S3-S8.

(R,S)-Ethyl-2-(5,5-diethyl-2,4-dimethyl-2-(pyridin-2-yl)-2,5-dihydro-1H-imidazol-1-yloxy)-2-phenylacetate $\left(2^{\mathbf{R S} / \mathrm{SR}}\right)$ : Yield $45 \%$, colorless crystals, m.p. $81-83{ }^{\circ} \mathrm{C}$ (hexane). ${ }^{1} \mathrm{H}-\mathrm{NMR}\left(400 \mathrm{MHz}, \mathrm{CDCl}_{3}\right): \delta=0.38$ $\left(\mathrm{t}, 3 \mathrm{H}, J=7 \mathrm{~Hz}, \mathrm{CH}_{3}\right), 1.02\left(\mathrm{t}, 3 \mathrm{H}, J=7 \mathrm{~Hz} \mathrm{CH}_{3}\right), 1.19\left(\mathrm{t}, 3 \mathrm{H}, J=7 \mathrm{~Hz}, \mathrm{CH}_{3}\right), 1.25-1.33\left(\mathrm{~m}, 2 \mathrm{H}, \mathrm{CH}_{2}\right)$, $1.53\left(\mathrm{ABq}, 1 \mathrm{H}, J=7,14 \mathrm{~Hz}, \mathrm{CH}_{2}\right), 1.82\left(\mathrm{ABq}, 1 \mathrm{H}, J=7,14 \mathrm{~Hz}, \mathrm{CH}_{2}\right), 1.95\left(\mathrm{~s}, 3 \mathrm{H}, \mathrm{CH}_{3}\right), 2.00\left(\mathrm{~s}, 3 \mathrm{H}, \mathrm{CH}_{3}\right)$, $4.04\left(\mathrm{ABq}, 1 \mathrm{H}, J=7,17.9 \mathrm{~Hz}, \mathrm{CH}_{2}-\mathrm{O}\right), 4.13\left(\mathrm{ABq}, 1 \mathrm{H}, J=7,17.9 \mathrm{~Hz}, \mathrm{CH}_{2}-\mathrm{O}\right), 5.74(\mathrm{~s}, 1 \mathrm{H}, \mathrm{C} \underline{\mathrm{H}}-\mathrm{Ph})$, 7.18-7.22 (m, 1H, Py), 7.30-7.35 (m, 3H, Ph), 7.36-7.41 (m, 2H, Ph), 7.48-7.53 (m, 1H, Py), 7.61-7.67 (m, $1 \mathrm{H}, \mathrm{Py}), 8.69-8.73(\mathrm{~m}, 1 \mathrm{H}, \mathrm{Py}) .{ }^{13} \mathrm{C}-\mathrm{NMR}\left(100 \mathrm{MHz}, \mathrm{CDCl}_{3}\right): \delta=8.68,10.50\left(2^{*} \mathrm{CH}_{3}, \mathrm{Et}\right), 13.80\left(\mathrm{CH}_{3}\right.$, $\mathrm{EtO}), 16.74\left(\underline{\mathrm{CH}}_{3}-\mathrm{CNN}\right), 23.30\left(\underline{\mathrm{CH}}_{3}-\mathrm{C}=\mathrm{N}\right), 27.42,29.86\left(2^{*} \mathrm{CH}_{2}, \mathrm{Et}\right), 60.59\left(\mathrm{CH}_{2}, \mathrm{EtO}\right), 81.20\left(\underline{C E t}_{2}\right)$, $84.81(\underline{\mathrm{CH}}-\mathrm{O}-\mathrm{N}), 96.34\left(\mathrm{Py}-\mathrm{C}-\mathrm{CH}_{3}\right), 119.84,121.62,128.01,128.07,128.29(\mathrm{Ar}), 135.62(\mathrm{CH}, 4-\mathrm{Py}), 137.37$ ( $\left.{ }^{i} \mathrm{Ph}\right), 148.53(\mathrm{CH}, 2 \mathrm{Py}), 164.99\left({ }^{i} \mathrm{Py}\right), 170.81(\mathrm{C}=\mathrm{O}), 173.47(\mathrm{C}=\mathrm{N}) . \mathrm{UV}(\mathrm{EtOH}): \lambda_{\max }(\log \varepsilon)=255(4.27)$. IR (neat): 623, 696, 752, 791, 1066, 1086, 1176, 1201, 1331, 1371, 1433, 1468, 1585, 1659, 1741, 2874, 2933, $2978 \mathrm{~cm}^{-1}$. Anal. calcd. for $\mathrm{C}_{24} \mathrm{H}_{31} \mathrm{~N}_{3} \mathrm{O}_{3}: \mathrm{C}, 70.39 ; \mathrm{H}, 7.63 ; \mathrm{N}, 10.26$; found: $\mathrm{C}, 70.55 ; \mathrm{H}, 7.84 ; \mathrm{N}, 10.29$. NMR assignments (600 MHz): SI, p. S9-S23.

(tert-Butyl-2-((5,5-diethyl-2,4-dimethyl-2-(pyridin-2-yl)-2,5-dihydro-1H-imidazol-1-yl)oxy)-2-methylpropanoate) (3). Yield 84\%. Colorless oil. ${ }^{1} \mathrm{H}$ NMR $\left(500 \mathrm{MHz}, \mathrm{CDCl}_{3}\right): \delta=0.71\left(\mathrm{t}, 3 \mathrm{H}, J=7.3 \mathrm{~Hz},{ }^{\mathrm{Et}} \mathrm{CH}_{3}\right)$, $0.98\left(\mathrm{t}, 3 \mathrm{H}, J=7.3 \mathrm{~Hz}{ }^{\mathrm{Et}} \mathrm{CH}_{3}\right), 0.99\left(\mathrm{~s}, 3 \mathrm{H}, \mathrm{CH}_{3}\right), 1.23\left(\mathrm{~s}, 3 \mathrm{H}, \mathrm{CH}_{3}\right), 1.32\left(\mathrm{~s}, 9 \mathrm{H}, 3 * \mathrm{CH}_{3}\right)$, $1.60\left(\mathrm{ABq}, 1 \mathrm{H}, J=7.3,14 \mathrm{~Hz}, \mathrm{CH}_{2}\right), 1.66-1.77\left(\mathrm{~m}, 2 \mathrm{H}, \mathrm{CH}_{2}\right), 1.86\left(\mathrm{~s}, 3 \mathrm{H}, \mathrm{CH}_{3}\right), 1.93\left(\mathrm{~s}, 3 \mathrm{H}, \mathrm{CH}_{3}\right)$, 2.00 (ABq, $\left.1 \mathrm{H}, J=7.3,14 \mathrm{~Hz}, \mathrm{CH}_{2}\right), 7.04-7.08$ (m, 1H, Py), 7.40-7.43 (m, 1H, Py), 7.49-7.54 (m, 2H, Ph), 7.52-7.57 (m, 1H, Py), 8.49-8.52 (m, 1H, Py). ${ }^{13} \mathrm{C}-\mathrm{NMR}\left(\mathrm{CDCl}_{3}, 125 \mathrm{MHz}\right): \delta=9.05,10.80\left(2^{*} \mathrm{CH}_{3}, \mathrm{Et}\right)$, $17.26\left(\mathrm{CH}_{3}-\mathrm{CNN}\right), 21.73,24.15,24.70\left(3^{*} \mathrm{CH}_{3}\right), 27.35,28.97\left(2^{*} \mathrm{CH}_{2}, \mathrm{Et}\right), 27.67\left(3^{*} \mathrm{CH}_{3}, \mathrm{tBu}\right), 80.53,81.12$, $81.85\left(\underline{\mathrm{CMe}}_{2}, \mathrm{CEt}_{2}, \underline{\mathrm{C}}^{\mathrm{t}} \mathrm{Bu}\right), 95.70\left(\mathrm{Py}-\underline{\mathrm{C}}-\mathrm{CH}_{3}\right), 121.33,121.66\left(2^{*} \mathrm{CH}, \mathrm{Py}\right), 135.45(\mathrm{CH}, 4-\mathrm{Py}), 147.74(\mathrm{CH}$, 2-Py), 163.94 ( $\left.{ }^{i} \mathrm{Py}\right), 173.36,173.53(\mathrm{C}=\mathrm{O}, \mathrm{C}=\mathrm{N})$. NMR assignments (600 MHz): SI, p S25-S38.

$\mathrm{UV}(\mathrm{EtOH}): \lambda_{\max }(\log \varepsilon)=256(3.51)$

IR(neat): 750, 788, 848, 1099, 1138, 1160, 1254, 1292, 1367, 1431, 1468, 1572, 1587, 1662, 1728, 2877, 2933, 2978.

Anal. calcd. for $\mathrm{C}_{22} \mathrm{H}_{35} \mathrm{~N}_{3} \mathrm{O}_{3}$ : C, 67.83; H, 9.06; N, 10.79; found: $\mathrm{C}, 67.69 ; \mathrm{H}, 8.89 ; \mathrm{N}, 10.51$.

$X R D$ analysis of alkoxyamine $2^{R S / S R}$. XRD data were obtained at room teperature on a Bruker Kappa Apex II CCD diffractometer using $\varphi, \omega$ scans of narrow $\left(0.5^{\circ}\right)$ frames with Mo K $\alpha$ radiation $(\lambda=0.71073 \AA)$, and a graphite monochromator. Absorption corrections were applied empirically using SADABS programs [51]. The structures were solved by direct methods and refined by full-matrix least-squares method against all $F^{2}$ in anisotropic approximation (beside the atoms $\mathrm{H}$ ) using the SHELX-97 programs set [52]. The $\mathrm{H}$ atoms positions were calculated with the riding model (Figure 10).

Crystallographic data for $2^{R S / S R}: T 296(2) K, \mathrm{C}_{24} \mathrm{H}_{31} \mathrm{~N}_{3} \mathrm{O}_{3}, F W=409.52$, monoclinic, $P 2{ }_{1} / \mathrm{c}, a=9.9606(4)$,

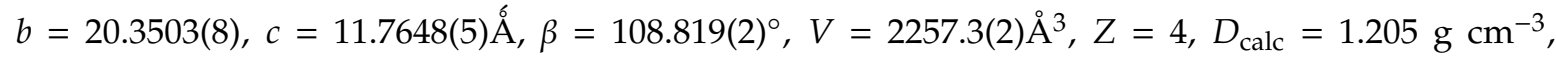


$\mu(\mathrm{Mo}-K \alpha)=0.080 \mathrm{~mm}^{-1}, F(000)=880,72,240$ measured reflections $\left(\theta_{\max }=27.19^{\circ}\right.$, completeness $99.4 \%), 5005$ independent $\left(R_{\mathrm{int}}=0.0388\right), 285$ parameters, $R_{1}=0.0616$ (for 3991 observed $\left.I>2 \sigma(I)\right)$, $w R_{2}=0.2000$ (all data), GooF $=1.03$, largest diff. peak and hole 0.61 and -0.47 e. $\mathrm{A}^{-3}$. The C7-methyl group is disordered by two positions C7a and C7b with 0.55:0.45(3) occupation ratio.

CCDC $1,829,288$ contain the supplementary crystallographic data for this paper. These data can be obtained free of charge via http://www.ccdc.cam.ac.uk/cgi-bin/catreq.cgi, or from the Cambridge Crystallographic Data Centre, 12 Union Road, Cambridge CB2 1EZ, UK; fax: (+44) 1223336033 ; or e-mail: deposit@ccdc.cam.ac.uk.

Molecules $2^{R S / S R}$ adopt conformations that are stabilized by two weak intramolecular hydrogen bonds: one between the nitrogen of the pyridine moiety and the methynic proton $\left(d_{\mathrm{H} \cdot \cdots \mathrm{N}}=2.59\right.$, $d_{\mathrm{C} \cdots \mathrm{N}}=3.172(3)$ Aand $\left.\langle\mathrm{NHC}\rangle=118^{\circ}\right)[26,53-56]$ and the other one between the ortho proton of the pyridyl moiety and the imino function $\left(d_{\mathrm{H} \cdots \mathrm{N}}=2.44, d_{\mathrm{C} \cdots \mathrm{N}}=2.777(3)\right.$ Aand $\left\langle\mathrm{NHC}>=102^{\circ}\right)$. The intermolecular interactions governing the crystal packing include the $\pi \ldots \pi$ interaction of phenyl groups (the separation of molecular planes within the stacks is 3.453(1) and the distance between ring centers Cg ... Cg 4.148 (2) $\AA$ ), which leads to the formation of the centrosymmetric dimers.

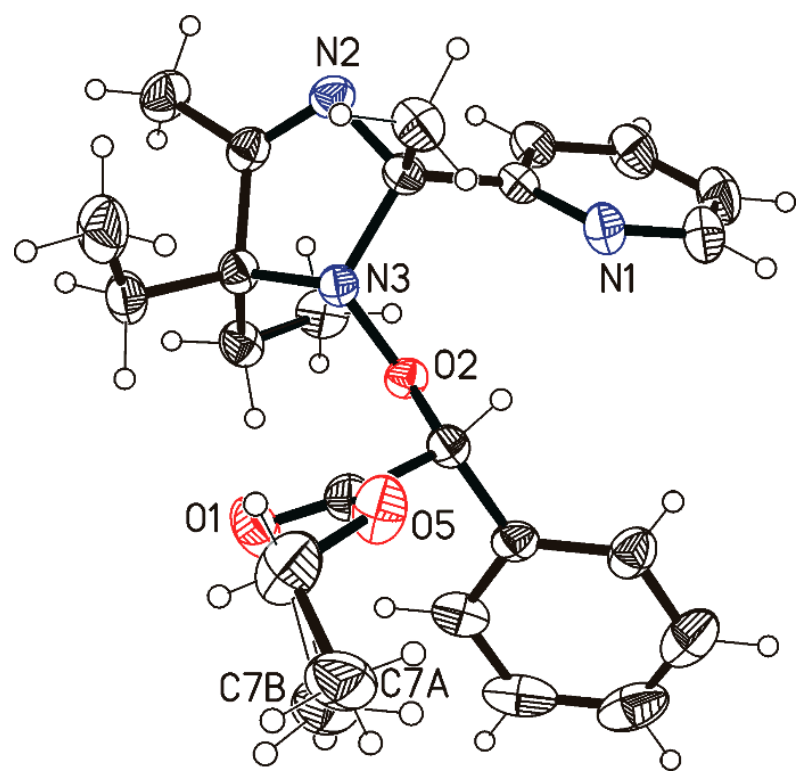

Figure 10. XRD structure of $2^{R S / S R}$. (Displacement ellipsoids are drawn at the $30 \%$ probability level).

EPR experiments. All the EPR experiments were performed on the Bruker Elexys E540 X-band spectrometer, using toluene $(0.2 \mathrm{~mL})$ as solvent. The concentration of species in all the experiments was $2 \times 10^{-4} \mathrm{M}$. These solutions have been prepared by the dilution method, from the stock solution of

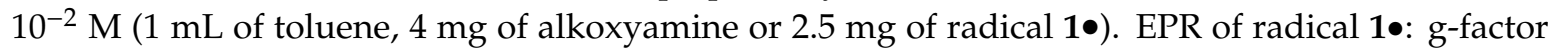
of radical 1• was calculated from the reference spectrum of TEMPO, g(TEMPO) $=2.00623$ [57]. The EPR spectrum of 1• was recording at the following parameters: microwave power $2 \mathrm{~mW}$, resolution-1024 points, number of scans 24 , conversion time $20.74 \mathrm{~ms}$, modulation amplitude $0.5 \mathrm{G}$, time constant $20.48 \mathrm{~ms}$.

Kinetics of alkoxyamine homolysis by EPR: to perform the experiments, the oxygen that is in the solvent was used as an alkyl radical trap. The kinetic data were collected as a growing second intergral EPR signal of forming nitroxyl radical. The EPR spectra of all the alkoxyamines were recorded at the following parameters: microwave power $2 \mathrm{~mW}$, resolution-1024 points, conversion time $19.55 \mathrm{~ms}$, modulation amplitude $1 \mathrm{G}$, time constant $20.48 \mathrm{~ms}$.

Homolysis of alkoxyamines in the absence of scavengers (Epimerization). The epimerization reaction was investigated by NMR. The experiments were performed as follows: $0.01 \mathrm{mmol}(\approx 5 \mathrm{mg})$ of alkoxyamine 
2 was solved in $0.58 \mathrm{~mL}$ of toluene- $\mathrm{d}_{8}$ in NMR tube. The solution was blown with Ar, the tube was sealed with a PTFE cap, and a heat-shrinkable tube. The process of epimerization was carried out at $345 \mathrm{~K}$ directly in the probe head of the NMR spectrometer.

Homolysis of alkoxyamines in the presence of scavengers. Experiments were performed by the above procedure with $0.50 \mathrm{~mL}$ toluene- $\mathrm{d}_{8}$ and $1 \mathrm{mmol}$ of scavenger $(0.080 \mathrm{~mL} \mathrm{BME}$ or $0.115 \mathrm{~mL} \mathrm{PhSH})$ as the reaction medium.

The experimental kinetic data were evaluated by numerical integration of the differential equations followed by a nonlinear least square fitting of the involved rate constants. The complete processing algorithm was implemented in the form of SciLab[58] script [59] (SI p. S200-S204).

Quantum chemical calculations. These were performed using a fast DFT code implemented in the PRIRODA program [60] and employing a PBE functional [61] with full-electron basis $\Lambda 01$ [62] (similar to the cc-pVDZ basis) as a gas-phase model. The transition states were connected with corresponding minima using the intrinsic reaction coordinate (IRC) procedure. Conformational analysis was performed with the computer program scan from Tinker package (MMFF94 force field) [63] and with the CREST program (GFN2-xTB method) [64]. Then, the geometries of all the conformers were optimized on the DFT/PBE/ $\Lambda 01$ level.

\section{Conclusions}

We synthesized three alkoxyamines based on the imidazoline radical with a pyridine functional group capable of complexation with metals. EPR and NMR were used to investigate the thermolysis of chiral alkoxyamines $2^{\mathrm{RR} / \mathrm{SS}}, 2^{\mathrm{RS} / \mathrm{RS}}$, and the results were compared with those for non-diastereomeric alkoxyamine 3. For NMR experiments, we used three different scavengers, namely $\beta$-mercaptoethanol, thiophenol, and TEMPO, to show the importance of choosing an appropriate radical trap. For EPR measurements, we used oxygen as a radical scavenger possessing different rate constants with alkyl radicals formed during the decay of alkoxyamines. That revealed that oxygen can produce incorrect results due to its low recombination rate constant with alkyl radicals. The biexponential growth of nitroxide can be obtained if additional processes such as isomerization occur with comparable rates. It is shown that only a careful analysis by NMR provides valid conclusions about the processes that take place. Careful analysis of the thermolysis products of the investigated alkoxyamines differentiated between $N$-inversion, epimerization, and reactions with radical scavengers. Kinetic measurements at different temperatures determined the activation energy of $\mathrm{N}$-inversion and the rate constants for homolysis. Additional side reactions of alkoxyamines with BME were detected and identified.

The alkoxyamine chirality affected our experiments with more than a two-fold difference in the homolysis rates for the two diastereomers (Table 1). The influence of alkoxyamine chirality on polymerization needs further study.

Supplementary Materials: The following are available online. NMR and EPR study of Diastereomeric Alkoxyamine's Homolysis.

Author Contributions: Conceptualization, E.B., S.R.A.M., I.K.; methodology, G.S., A.G., M.E.; software, D.P., A.G.; formal analysis, S.C., G.S., A.G., investigation, D.M., I.K. S.C., T.R., G.S., A.G.; writing- S.C., G.S., A.G., writing-review and editing, E.B.; supervision, E.B. All authors have read and agreed to the published version of the manuscript.

Funding: This research was funded by the Ministry of Education and Science of the Russian Federation (state contract no. №14.W03.31.0034) and RFBR (grant No 20-33-90133).

Acknowledgments: The authors thank the Multi-Access Chemical Research Center of the Siberian Branch of the Russian Academy of Sciences, for spectral and analytical measurements. Support from the Supercomputer Center of the Novosibirsk State University is also appreciated. The authors are thankful to Professor Michael Bowman for fruitful discussion.

Conflicts of Interest: The authors declare no conflict of interest. 


\section{References}

1. Solomon, D.; Rizzardo, E. Cacioli, P. Polymerization Process and Polymers Produced thereby. U.S. Patent 4,581,429, 8 April 1986.

2. Matyjaszewski, K. Controlled radical polymerization. Curr. Opin. Solid State Mater. Sci. 1996, 1, 769-776. [CrossRef]

3. Studer, A. Tin-free radical chemistry using the persistent radical effect: Alkoxyamine isomerization, addition reactions and polymerizations. Chem. Soc. Rev. 2004, 33, 267-273. [CrossRef]

4. Hawker, C.J.; Bosman, A.W.; Harth, E. New polymer synthesis by nitroxide mediated living radical polymerizations. Chem. Rev. 2001, 101, 3661-3688. [CrossRef] [PubMed]

5. Studer, A.; Schulte, T. Nitroxide-mediated radical processes. Chem. Rec. 2005, 5, 27-35. [CrossRef] [PubMed]

6. Braunecker, W.A.; Matyjaszewski, K. Controlled/living radical polymerization: Features, developments, and perspectives. Prog. Polym. Sci. 2007, 32, 93-146. [CrossRef]

7. Charleux, B.; Nicolas, J. Water-soluble SG1-based alkoxyamines: A breakthrough in controlled/living free-radical polymerization in aqueous dispersed media. Polymer 2007, 48, 5813-5833. [CrossRef]

8. Grubbs, R.B. Nitroxide-mediated radical polymerization: Limitations and versatility. Polym. Rev. 2011, 51, 104-137. [CrossRef]

9. Tebben, L.; Studer, A. Nitroxides: Applications in Synthesis and in Polymer Chemistry. Angew. Chem. Int. Ed. 2011, 50, 5034-5068. [CrossRef]

10. Gigmes, D.; Marque, S. Nitroxide-Mediated Polymerization and its Applications. In Encyclopedia of Radicals in Chemistry, Biology, and Materials; Chatgilialoglu, C., Studer, A., Eds.; Wiley: Chichester, UK, 2012.

11. Tsarevsky, N.V.; Sumerlin, B.S. (Eds.) Fundamentals of Controlled/Living Radical Polymerization; Royal Society Chemistry: London, UK, 2013; pp. 1-364.

12. Astolfi, P.; Greci, L.; Stipa, P.; Rizzoli, C.; Ysacco, C.; Rollet, M.; Autissier, L.; Tardy, A.; Guillaneuf, Y.; Gigmes, D. Indolinic nitroxides: Evaluation of their potential as universal control agents for nitroxide mediated polymerization. Polym. Chem. 2013, 4, 3694-3704. [CrossRef]

13. Nicolas, J.; Guillaneuf, Y.; Lefay, C.; Bertin, D.; Gigmes, D.; Charleux, B. Nitroxide-mediated polymerization. Prog. Polym. Sci. 2013, 38, 63-235. [CrossRef]

14. Tardy, A.; Delplace, V.; Siri, D.; Lefay, C.; Harrisson, S.; de Fatima Albergaria Pereira, B.; Charles, L.; Gigmes, D.; Nicolas, J.; Guillaneuf, Y. Scope and limitations of the nitroxide-mediated radical ring-opening polymerization of cyclic ketene acetals. Polym. Chem. 2013, 4, 4776-4787. [CrossRef]

15. Pan, X.; Tasdelen, M.A.; Laun, J.; Junkers, T.; Yagci, Y.; Matyjaszewski, K. Photomediated controlled radical polymerization. Prog. Polym. Sci. 2016, 62, 73-125. [CrossRef]

16. Marque, S. Influence of the nitroxide structure on the homolysis rate constant of alkoxyamines: A Taft-Ingold analysis. J. Org. Chem. 2003, 68, 7582-7590. [CrossRef] [PubMed]

17. Fischer, H.; Kramer, A.; Marque, S.R.; Nesvadba, P. Steric and Polar Effects of the Cyclic Nitroxyl Fragment on the C-ON Bond Homolysis Rate Constant. Macromolecules 2005, 38, 9974-9984. [CrossRef]

18. Audran, G.; Bikanga, R.; Brémond, P.; Joly, J.-P.; Marque, S.R.A.; Nkolo, P. Normal, Leveled, and Enhanced Steric Effects in Alkoxyamines Carrying a $\beta$-Phosphorylated Nitroxyl Fragment. J. Org. Chem. 2017, 82, 5702-5709. [CrossRef]

19. Gryn'ova, G.; Lin, C.Y.; Coote, M.L. Which side-reactions compromise nitroxide mediated polymerization? Polym. Chem. 2013, 4, 3744-3754. [CrossRef]

20. Bertin, D.; Gigmes, D.; Marque, S.R.; Tordo, P. Polar, steric, and stabilization effects in alkoxyamines C-ON bond homolysis: A multiparameter analysis. Macromolecules 2005, 38, 2638-2650. [CrossRef]

21. Audran, G.; Bagryanskaya, E.; Bagryanskaya, I.; Edeleva, M.; Marque, S.R.; Parkhomenko, D.; Tretyakov, E.; Zhivetyeva, S. Zinc (II) Hexafluoroacetylacetonate Complexes of Alkoxyamines: NMR and Kinetic Investigations. First Step for a New Way to Prepare Hybrid Materials. ChemistrySelect 2017, 2, 3584-3593. [CrossRef]

22. Hodgson, J.L.; Yeh Lin, C.; Coote, M.L.; Marque, S.R.A.; Matyjaszewski, K. Linear Free-Energy Relationships for the Alkyl Radical Affinities of Nitroxides: A Theoretical Study. Macromolecules 2010, 43, 3728-3743. [CrossRef]

23. Bremond, P.; Marque, S.R.A. First proton triggered $\mathrm{C}-\mathrm{ON}$ bond homolysis in alkoxyamines. Chem. Commun. 2011, 47, 4291-4293. [CrossRef] 
24. Edeleva, M.V.; Kirilyuk, I.A.; Zhurko, I.F.; Parkhomenko, D.A.; Tsentalovich, Y.P.; Bagryanskaya, E.G. $\mathrm{pH}-$ Sensitive $\mathrm{C}-\mathrm{ON}$ bond homolysis of alkoxyamines of imidazoline series with multiple ionizable groups as an approach for control of Nitroxide Mediated Polymerization. J. Org. Chem. 2011, 76, 5558-5573. [CrossRef]

25. Brémond, P.; Koïta, A.; Marque, S.R.A.; Pesce, V.; Roubaud, V.; Siri, D. Chemically Triggered C-ON Bond Homolysis of Alkoxyamines. Quaternization of the Alkyl Fragment. Org. Lett. 2012, 14, 358-361. [CrossRef] [PubMed]

26. Audran, G.; Bikanga, R.; Bremond, P.; Edeleva, M.; Joly, J.P.; Marque, S.R.A.; Nkolo, P.; Roubaud, V. How intramolecular hydrogen bonding (IHB) controls the $\mathrm{C}-\mathrm{ON}$ bond homolysis in alkoxyamines. Org. Biomol. Chem. 2017, 15, 8425-8439. [CrossRef] [PubMed]

27. Audran, G.; Bagryanskaya, E.; Bagryanskaya, I.; Brémond, P.; Edeleva, M.; Marque, S.R.; Parkhomenko, D.; Tretyakov, E.; Zhivetyeva, S. C-ON bond homolysis of alkoxyamines triggered by paramagnetic copper (ii) salts. Inorg. Chem. Front. 2016, 3, 1464-1472. [CrossRef]

28. Audran, G.; Bagryanskaya, E.G.; Bagryanskaya, I.Y.; Edeleva, M.; Kaletina, P.; Marque, S.R.A.; Parkhomenko, D.; Tretyakov, E.V.; Zhivetyeva, S.I. The effect of the oxophilic $\mathrm{Tb}(\mathrm{III})$ cation on CON bond homolysis in alkoxyamines. Inorg. Chem. Commun. 2018, 91, 5-7. [CrossRef]

29. Audran, G.; Bagryanskaya, E.; Bagryanskaya, I.; Edeleva, M.; Joly, J.-P.; Marque, S.R.A.; Iurchenkova, A.; Kaletina, P.; Cherkasov, S.; Hai, T.T.; et al. How intramolecular coordination bonding (ICB) controls the homolysis of the $\mathrm{C}-\mathrm{ON}$ bond in alkoxyamines. RSC Adv. 2019, 9, 25776-25789. [CrossRef]

30. Audran, G.; Brémond, P.; Franconi, J.-M.; Marque, S.R.A.; Massot, P.; Mellet, P.; Parzy, E.; Thiaudière, E. Alkoxyamines: A new family of pro-drugs against cancer. Concept for theranostics. Org. Biomol. Chem. 2014, 12, 719-723. [CrossRef]

31. Gryn'ova, G.; Smith, L.M.; Coote, M.L. Computational design of $\mathrm{pH}$-switchable control agents for nitroxide mediated polymerization. Phys. Chem. Chem. Phys. 2017, 19, 22678-22683. [CrossRef]

32. Klinska, M.; Smith, L.M.; Gryn'ova, G.; Banwell, M.G.; Coote, M.L. Experimental demonstration of $\mathrm{pH}$-dependent electrostatic catalysis of radical reactions. Chem. Sci. 2015, 6, 5623-5627. [CrossRef]

33. Hill, N.S.; Coote, M.L. Rational design of photo-cleavable alkoxyamines for polymerization and synthesis. Phys. Chem. Chem. Phys. 2020, 22, 19680-19686. [CrossRef]

34. Edeleva, M.V.; Marque, S.R.A.; Bagryanskaya, E.G. Imidazoline and imidazolidine nitroxides as controlling agents in nitroxide-mediated pseudoliving radical polymerization. Russ. Chem. Rev. 2018, 87, 328-349. [CrossRef]

35. Ananchenko, G.S.; Fischer, H. Decomposition of model alkoxyamines in simple and polymerizing systems. I. 2, 2, 6, 6-tetramethylpiperidinyl-N-oxyl-based compounds. J. Polym. Sci. Part A Polym. Chem. 2001, 39, 3604-3621. [CrossRef]

36. Ananchenko, G.S.; Souaille, M.; Fischer, H.; Le Mercier, C.; Tordo, P. Decomposition of model alkoxyamines in simple and polymerizing systems. II. Diastereomeric N-(2-methylpropyl)-N-(1-diethyl-phosphono-2, 2-dimethyl-propyl)-aminoxyl-based compounds. J. Polym. Sci. Part A Polym. Chem. 2002, 40, 3264-3283. [CrossRef]

37. Ananchenko, G.; Marque, S.; Gigmes, D.; Bertin, D.; Tordo, P. Diastereomeric excess upon cleavage and reformation of diastereomeric alkoxyamines. Org. Biomol. Chem. 2004, 2, 709-715. [CrossRef] [PubMed]

38. Marque, S.; Le Mercier, C.; Tordo, P.; Fischer, H. Factors Influencing the C-O- Bond Homolysis of Trialkylhydroxylamines. Macromolecules 2000, 33, 4403-4410. [CrossRef]

39. Edeleva, M.; Marque, S.R.; Bertin, D.; Gigmes, D.; Guillaneuf, Y.; Morozov, S.V.; Bagryanskaya, E.G. Hydrogen-transfer reaction in nitroxide mediated polymerization of methyl methacrylate: 2, 2-Diphenyl3-phenylimino-2, 3-dihydroindol-1-yloxyl nitroxide (DPAIO) vs. TEMPO. J. Polym. Sci. Part A Polym. Chem. 2008, 46, 6828-6842. [CrossRef]

40. Edeleva, M.V.; Kirilyuk, I.A.; Zubenko, D.P.; Zhurko, I.F.; Marque, S.R.A.; Gigmes, D.; Guillaneuf, Y.; Bagryanskaya, E.G. Kinetic study of H-atom transfer in imidazoline-, imidazolidine-, and pyrrolidine-based alkoxyamines: Consequences for nitroxide-mediated polymerization. J. Polym. Sci. Part A Polym. Chem. 2009, 47, 6579-6595. [CrossRef]

41. Edeleva, M.; Marque, S.R.; Bertin, D.; Gigmes, D.; Guillaneuf, Y.; Bagryanskaya, E. Chemically Induced Dynamic Nuclear Polarization during the Thermolysis of Alkoxyamines: A New Approach to Detect the Occurrence of H-Transfer Reactions. Polymers 2010, 2, 364-377. [CrossRef] 
42. Tormyshev, V.M.; Genaev, A.M.; Sal'nikov, G.E.; Rogozhnikova, O.Y.; Troitskaya, T.I.; Trukhin, D.V.; Mamatyuk, V.I.; Fadeev, D.S.; Halpern, H.J. Triarylmethanols bearing bulky aryl groups and the NOESY/EXSY experimental observation of two-ring-flip mechanism for helicity reversal of molecular propellers. Eur. J. Org. Chem. 2012, 3, 623-629. [CrossRef]

43. Stephenson, D.S.; Binsch, G. Iterative computer analysis of complex exchange-broadened NMR bandshapes. J. Magn. Reson. (1969) 1978, 32, 145-152. [CrossRef]

44. Busfield, W.K.; Jenkins, I.D.; Thang, S.H.; Moad, G.; Rizzardo, E.; Solomon, D.H. Slow nitrogen inversion-N-O rotation in 2-alkoxy-1,1,3,3-tetramethylisoindolines. J. Chem. Soc. Chem. Commun. 1985, 18, 1249-1250. [CrossRef]

45. Anderson, J.E.; Casarini, D.; Corrie, J.E.T.; Lunazzi, L. The measurement of the one-fold rotational barrier of eclipsed bonds. A dynamic NMR determination of $\mathrm{N}-\mathrm{O}$ or $\mathrm{N}-\mathrm{CH} 2$ bond rotation in $\mathrm{N}$-alkoxy- or N-alkyl-2,2,6,6-tetramethylpiperidines. J. Chem. Soc. Perkin Trans. 2 1993, 7, 1299-1304. [CrossRef]

46. Bagryanskaya, E.G.; Marque, S.R.A. Chapter 2 Kinetic Aspects of Nitroxide Mediated Polymerization. In Nitroxide Mediated Polymerization: From Fundamentals to Applications in Materials Science; Gigmes, D., Ed.; The Royal Society of Chemistry: London, UK, 2016; pp. 45-113.

47. Kothe, T.; Marque, S.; Martschke, R.; Popov, M.; Fischer, H. Radical reaction kinetics during homolysis of $\mathrm{N}$-alkoxyamines: Verification of the persistent radical effect. J. Chem. Soc. Perkin Trans. 2 1998, 7, 1553-1560. [CrossRef]

48. Keisuke, M.; Takao, Y. Studies on Stable Free Radicals. III. Reactions of Stable Nitroxide Radicals with S-Radicals Derived from Benzenethiols and Thiamine. Bull. Chem. Soc. Jpn. 1969, 42, 1942-1947.

49. Reznikov, V.A.; Volodarskii, L.B. Synthesis of bifunctional derivatives of nitroxyl radicals of imidazoline. Chem. Heterocycl. Compd. 1990, 26, 643-648. [CrossRef]

50. Matyjaszewski, K.; Woodworth, B.E.; Zhang, X.; Gaynor, S.G.; Metzner, Z. Simple and efficient synthesis of various alkoxyamines for stable free radical polymerization. Macromolecules 1998, 31, 5955-5957. [CrossRef]

51. SADABS; Version 2008/1; Bruker AXS: Madison, WI, USA, 2008.

52. Sheldrick, G. A short history of SHELX. Acta Crystallogr. Sect. A 2008, 64, 112-122. [CrossRef]

53. Rowland, R.S.; Taylor, R. Intermolecular Nonbonded Contact Distances in Organic Crystal Structures: Comparison with Distances Expected from van der Waals Radii. J. Phys. Chem. 1996, 100, 7384-7391. [CrossRef]

54. Murray, J.; Politzer, P. Molecular Surfaces, van der Waals Radii and Electrostatic Potentials in Relation to Noncovalent Interactions. Croat. Chem. Acta 2009, 82, 267-275.

55. Guerret, O.; Couturier, J.-L.; Chauvin, F.; El-Bouazzy, H.; Bertin, D.; Gigmes, D.; Marque, S.; Fischer, H.; Tordo, P. Influence of Solvent and Polymer Chain Length on the Hemolysis of SG1-Based Alkoxyamines. In Advances in Controlled/Living Radical Polymerization; American Chemical Society: Washington, DC, USA, 2003; Volume 854, pp. 412-423.

56. Jeffrey, G.A.; Saenger, W. (Eds.) Hydrogen Bonding in Proteins. In Hydrogen Bonding in Biological Structures; Springer: Berlin/Heidelberg, Germany, 1991; pp. 351-393.

57. Rockenbauer, A.; Györ, M.; Hideg, K.; Hankovszky, H.O. Investigation of naturally abundant $17 \mathrm{O}$ hyperfine satellites in the electron spin resonance spectrum of 5- and 6-membered cyclic nitroxide (aminoxyl) radicals. J. Chem. Soc. Chem. Commun. 1985, 23, 1651-1653. [CrossRef]

58. Scilab Enterprises. Scilab: Free and Open Source Software for Numerical Computation; Version 5.5.0.; Scilab Enterprises: Orsay, France, 2012.

59. Shernyukov, A.V.; Genaev, A.M.; Salnikov, G.E.; Shubin, V.G.; Rzepa, H.S. Elevated reaction order of 1,3,5-tri-tert-butylbenzene bromination as evidence of a clustered polybromide transition state: A combined kinetic and computational study. Org. Biomol. Chem. 2019, 17, 3781-3789. [CrossRef] [PubMed]

60. Laikov, D.N.; Ustynyuk, Y.A. PRIRODA-04: A quantum-chemical program suite. New possibilities in the study of molecular systems with the application of parallel computing. Russ. Chem. Bull. 2005, 54, 820-826. [CrossRef]

61. Perdew, J.P.; Burke, K.; Ernzerhof, M. Generalized Gradient Approximation Made Simple. Phys. Rev. Lett. 1996, 77, 3865-3868. [CrossRef] [PubMed]

62. Laikov, D.N. A new class of atomic basis functions for accurate electronic structure calculations of molecules. Chem. Phys. Lett. 2005, 416, 116-120. [CrossRef] 
63. Rackers, J.A.; Wang, Z.; Lu, C.; Laury, M.L.; Lagardère, L.; Schnieders, M.J.; Piquemal, J.-P.; Ren, P.; Ponder, J.W. Tinker 8: Software Tools for Molecular Design. J. Chem. Theory Comput. 2018, 14, 5273-5289. [CrossRef]

64. Pracht, P.; Bohle, F.; Grimme, S. Automated exploration of the low-energy chemical space with fast quantum chemical methods. Phys. Chem. Chem. Phys. 2020, 22, 7169-7192. [CrossRef]

Sample Availability: Samples of the compounds alkoxyamines $2^{\mathrm{RS} / \mathrm{SR}}, 2^{\mathrm{RR} / \mathrm{SS}}$ and 3 are available from the authors.

Publisher's Note: MDPI stays neutral with regard to jurisdictional claims in published maps and institutional affiliations.

(C) 2020 by the authors. Licensee MDPI, Basel, Switzerland. This article is an open access article distributed under the terms and conditions of the Creative Commons Attribution (CC BY) license (http://creativecommons.org/licenses/by/4.0/). 